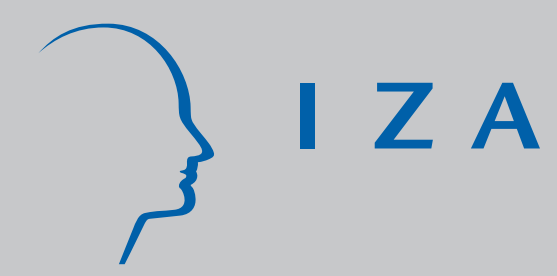

IZA DP No. 100

Immigrant Assimilation and Welfare Participation:

Do Immigrants Assimilate Into or Out-of Welfare

$J$ örgen Hansen

Magnus Lofstrom

December 1999 


\title{
Immigrant Assimilation and Welfare Participation: Do Immigrants Assimilate Into or Out-of Welfare?
}

\author{
Jörgen Hansen \\ IZA, Bonn
}

Magnus Lofstrom

IZA, Bonn

\author{
Discussion Paper No. 100 \\ December 1999
}

\author{
IZA \\ P.O. Box 7240 \\ D-53072 Bonn \\ Germany \\ Tel.: +49-228-3894-0 \\ Fax: +49-228-3894-210 \\ Email: iza@iza.org
}

This Discussion Paper is issued within the framework of IZA's research areas Mobility and Flexibility of Labor Markets, The Welfare State and Labor Markets, and General Labor Economics. Any opinions expressed here are those of the author(s) and not those of the institute. Research disseminated by IZA may include views on policy, but the institute itself takes no institutional policy positions.

The Institute for the Study of Labor (IZA) in Bonn is a local and virtual international research center and a place of communication between science, politics and business. IZA is an independent, nonprofit limited liability company (Gesellschaft mit beschränkter Haftung) supported by the Deutsche Post AG. The center is associated with the University of Bonn and offers a stimulating research environment through its research networks, research support, and visitors and doctoral programs. IZA engages in (i) original and internationally competitive research in all fields of labor economics, (ii) development of policy concepts, and (iii) dissemination of research results and concepts to the interested public. The current research program deals with (1) mobility and flexibility of labor markets, (2) internationalization of labor markets and European integration, (3) the welfare state and labor markets, (4) labor markets in transition, (5) the future of work, (6) project evaluation and (7) general labor economics.

IZA Discussion Papers often represent preliminary work and are circulated to encourage discussion. Citation of such a paper should account for its provisional character. 
IZA Discussion Paper No. 100

December 1999

\section{ABSTRACT}

\section{Immigrant Assimilation and Welfare Participation: Do Immigrants Assimilate Into or Out-of Welfare?}

This paper analyzes differences in welfare utilization between immigrants and natives in Sweden using a large panel data set, LINDA, for the years 1990 to 1996 . Both welfare expenditures and immigration increased in Sweden in the 1990's. We find that immigrants use welfare to a greater extent than natives and that non-refugee immigrants utilize social assistance less than refugee immigrants. Differences in welfare participation and number of months on welfare between immigrants and natives cannot be explained by observable socioeconomic characteristics. Using a random effects probit model, we find that immigrants lower their participation rates in welfare with time spent in Sweden. Refugees display substantially higher public assistance participation rates upon arrival in Sweden compared to non-refugee immigrants, but they assimilate out-of welfare at a faster rate than non-refugee immigrants. Neither immigrant group is predicted to reach the participation rates of native households within a 20 year period in Sweden. A fixed effects logit model supports these findings. The predicted differences in the length of social assistance spells follow a very similar pattern. Simulations of the move to a national uniform benefits structure in 1998 show a decrease in the participation rate and in expenditures.

JEL Classification: H53, I30, I38, J15, J61

Keywords: Welfare, immigration, assimilation, panel data

Jörgen Hansen

IZA

P.O. Box 7240

D-53072 Bonn

Germany

Tel: $49-2283894223$

Fax: 49-228 3894210

Email: hansen@iza.org

\footnotetext{
"We would like to thank Thomas Bauer, Anders Björklund, Don DeVoretz, participants at the CEPR/TSER workshop on Labor Demand, Education and the Dynamics of Social Exclusion at Bar-llan University and seminar participants at Simon Fraser University for helpful comments. Financial support from the European Commission (grant SOE2-CT97-3052) and the Swedish Council for Social Research is gratefully acknowledged.
} 


\section{Introduction}

There has been a dramatic increase in the expenditure on social assistance (SA) in Sweden since the early 1980 's ${ }^{1}$. According to the National Board of Health and Welfare, total real expenditures between 1983 and 1996 increased from 4.4 billion Swedish kronor (SEK) to 11.9 billion SEK. As we will show, central to the increase in welfare costs is immigration. For example, by the mid 1990's, expenditures on social assistance for immigrants equaled that of natives, even though immigrants represented only 10-11 percent of the total population. Immigrants are also greatly over-represented in the welfare population in the U.S. and Germany, (see for example, Bean, Van Hook and Glick, 1997; Borjas and Trejo, 1991 and Riphahn, 1998).

It is quite clear that the concern about immigrant welfare usage is not specific to Sweden, but is also central to the immigration debates in other countries. For example, concerns about rising welfare costs in the U.S. led Congress to pass The Personal Responsibility and Work Opportunity Reconciliation Act of 1996, which denies noncitizens the right to receive most types of public assistance. The concerns about immigrant over-utilization of public assistance are obvious in Germany as well. Immigrants without permanent residency in Germany may lose the right to stay in the country or may be denied residency extensions if they rely on social assistance.

In Sweden, the main reason for the growth in welfare expenditure is, not surprisingly, an increase in the utilization of SA. In 1983, 7.8 percent of all households received SA. This figure had increased to 10.7 percent by 1996 . This represents a quite remarkable increase of over 37 percent. The increase is especially strong among the

\footnotetext{
${ }^{1}$ The term social assistance is used synonymously with public assistance and welfare in this paper.
} 
immigrant population. In particular, households from refugee countries are overrepresented among those households that receive SA. During the same period, the proportion of immigrants in the Swedish population has increased significantly. In 1983 the proportion of foreign-born individuals in Sweden was 7.6 percent. This had increased to 10.8 percent in 1996 . The over-representation of immigrants in the welfare population in combination with the increase in immigration can also explain part of the increase in welfare costs. Welfare expenditures also grew because of an increase in the number of months that households receive SA. During this period, the average number of months on SA increased from 4.2 months in 1983 to 5.5 months in 1996.

One important reason for the increase in welfare participation, and the consequent growth in expenditures, is the growth in the unemployment rate in the 1990's in Sweden, which grew from 1.7 percent in 1990 to slightly more than 8 percent in 1996 . For immigrants, the labor market deteriorated even more. In 1990, approximately 4 percent of the immigrant population was unemployed. This had increased to 23 percent by 1996 . The increase in welfare expenditures in Sweden in the 1990's can partly be explained by the large inflows of immigrants who arrived during this period who were not eligible for unemployment insurance and therefore had to rely on social assistance for their subsistence.

In this paper we try to answer three questions central to the debate of immigrant welfare utilization by using a unique large Swedish panel data set, Longitudinal Individual Data (LINDA). The first question we ask is whether the over-representation of immigrants among public assistance receiving households is due to differences in observable characteristics, such as level of education, or if it is due to behavioral 
differences between immigrants and natives (i.e. dissimilarity in the reservation wage) or differences in the labor markets faced by immigrants and natives (possibly due to discrimination). If the higher rates of welfare participation depend on differences in educational attainment, then policies directed towards increasing the educational level among immigrants may reduce the fiscal burden of social assistance in the future. However, if the observed differences in SA utilization depend on differences in preferences, then these types of policies would have a very limited effect, if any effect at all.

The second question deals with the important long term effects of immigration on welfare expenditures. Are immigrants likely to assimilate "into" or "out-of" welfare dependency, i.e. do immigrants increase or decrease their participation in social assistance with time spent in the host country? If immigrants' participation rates will change with time spent in the new country, the initial, upon arrival, costs of welfare should not be used to infer lifetime welfare costs of immigrants. For example, if immigrants assimilate out-of welfare, initial welfare costs will overstate the long run social assistance expenditures incurred by the immigrant population.

A third important question to answer in this context is what expected effects a reform in eligibility rules and benefit levels may have on both the utilization and the duration of welfare. In fact, such a reform did take place in Sweden in 1998, but there have been no studies - before or after - about the expected effects of the reform. In this paper, we will try to assess the impact of this reform on social assistance dependency using estimates from our model. 
Previous studies of immigrant welfare dependency in the economics literature generally find that immigrants are on average more likely to receive welfare than native born individuals. However, differences in observable socioeconomic characteristics explain greater participation rates among immigrants than natives in the U.S., Australia and Germany (Blau, 1984; Maani, 1993 and Riphahn, 1998, respectively). Previous studies have also found that time spent in the host country affect participation rates of immigrants. For example, in the U.S., Canada and Germany immigrants appear to increase welfare utilization with time spent in the new country (Borjas and Trejo, 1991 and 1993; Borjas and Hilton, 1996; Baker and Benjamin, 1995 and Riphahn, 1998). In other words, the existing literature suggests that immigrants assimilate into welfare dependency.

The longitudinal data used in this paper provides a clear advantage over the data used in previous studies. Most of the above mentioned papers utilized cross-sectional data, except for two, Borjas and Hilton (1996) and Riphahn (1998), who used panel data for the U.S. and Germany, respectively. Borjas and Hilton estimate linear probability models with fixed effects using a relatively short panel based on survey information. Riphahn controls for both unobserved heterogeneity and attrition. However, the data is not a representative sample of immigrants in Germany. Unfortunately, it only includes a small sample of guest workers and no refugees.

In this paper we take advantage of a recently collected large representative panel data set containing information on more than 300,000 individuals annually for the period 1990 to 1996 . The data is collected from administrative records implying essentially no attrition and less measurement error than what would be expected in survey data. Another 
significant advantage is that the longitudinal data set allows us to use methods controlling for unobserved heterogeneity. It is essential to control for unobserved effects since many of the factors determining whether a household receives welfare or not, including the reservation wage and stigma effects from participating in welfare programs, are unobserved by the econometrician.

The key findings in this paper are that immigrants are more likely to participate in the social assistance program than natives even when observable characteristics are controlled for and that immigrants assimilate out-of welfare with time spent in the new country. The former of these findings contradict what has been found previously in the literature. The self-selection of immigrants coming to a generous welfare state is likely to be one of the reasons for this result. We also find that immigrants reduce welfare participation rates with time spent in the new country. Although refugees display substantially higher participation rates upon arrival compared to non-refugee immigrants, they assimilate out-of welfare much more rapidly than their non-refugee counterparts.

The result that immigrants assimilate out-of welfare appears to contradict previous findings in regards to the assimilation of immigrants' welfare utilization. However, even after 20 years in the host country we find that both refugee and nonrefugee immigrants show significantly higher social assistance participation rates than statistically similar natives by between 5 and 7 percentage points. These numbers are quite close to the findings of Borjas and Hilton (1996) and Baker and Benjamin (1995). These results suggest that immigrants in an extremely generous welfare state, like Sweden, display similar welfare participation behavior as immigrants in less generous 
welfare states, like the U.S. and Canada, relative to natives after having spent some time in the new host country.

The paper is organized in the following way. In Sections 2 and 3 we give background information about immigration into Sweden and the social assistance program. Section 4 describes the data and variables while Section 5 depicts trends and differences, between immigrants and natives, in welfare participation. In Section 6 we test whether differences in welfare utilization can be explained by differences in socioeconomic characteristics. Assimilation issues are also analyzed in this section. In Section 7 we simulate the estimated impact of the change from municipally determined benefit levels to a nationally unified benefit level that took place in 1998. Finally, we conclude in Section 8.

\section{Historical Background - Immigration into Sweden}

The inflow of immigrants to Sweden has undergone a number of changes during the last six decades. Figure 1 shows annual immigration to Sweden from 1940 to 1998, both in terms of actual immigrant inflow and inflow expressed as proportion of the population in the corresponding year. Because of limited population growth during this period, these two measures closely coincide most of the years. Overall, annual immigration has amounted to about 0.4 percent of the population, but notably higher during the 1990's. This is a relatively high proportion compared to other Western countries. For example, the corresponding figure for the United States was around 0.3 
percent in the 1980's and 0.4 percent in the 1990's. ${ }^{2}$ Naturally, the large inflow of immigrants has also changed the composition of the population in Sweden. In 1991, about 10 percent of the Swedish population were born outside Sweden. Again, this is a quite high figure compared to other countries. For example, in 1991 the share of foreigners in the population was 7.9 percent in the US and 6.9 percent in Germany. The average for the European Union was 3.0 percent (Zimmermann, 1995).

The variation in the inflow of immigrants is evident from Figure 1. In fact, we can identify three different phases where immigration increased substantially between 1940 and 1998; in the immediate years following World War II, in the late 1960's and early 1970 's, and finally in the late 1980's and early 1990's. In the period around World War II, there was a substantial inflow of refugees to Sweden, especially from the Nordic countries. During the following 20 years, there was an annual inflow of about 25,000 people (corresponding to about 0.35 percent of the population). From the mid 1960's until the early 1970's, there was a large increase in immigration to Sweden. During these years, the annual inflow of immigrants amounted to about 1 percent of the population. The reason for the increase in immigration was active recruitment of labor conducted by the booming Swedish industry, which faced a shortage of unskilled labor during this period. A large fraction (about 60 percent) of the recruited labor force came from the Nordic countries (especially Finland). In the early 1970's, this recruitment stopped, and the number of immigrants dropped to levels slightly above those that prevailed in the 1950's. The third big increase in the inflow of immigrants took place in the late 1980's and early 1990's. The main reasons for the rise in immigration during this period were

\footnotetext{
2 Source: Statistical Abstract of the United States, 1998. The data for the 1990's is for the years 1990 to 1996.
} 
the war between Iran and Iraq and the political instability in the Balkans. The average inflow during this period was around 0.7 percent of the population.

The reasons people immigrate to Sweden have changed substantially during the post-war period. In principle, we can distinguish between three categories of immigrants, based on the reasons for immigration: economic migrants (due to the recruitment of labor), tied movers (i.e. family ties) and refugees. In the late 1940's, a large fraction of the immigrants arrived in Sweden as refugees. However, in the period from 1950 to 1970 , most of the immigrants were recruited by the Swedish industry or they arrived because of family ties. From 1970 and onwards, the proportion of immigrants arriving as refugees has increased significantly, from less than 10 percent of the immigrant inflow in 1970 to about 70 percent in the early 1990 's. ${ }^{3}$ In 1994 , this proportion dropped from 70 percent to about 50 percent, mostly due to the improved conditions in the Balkan countries.

\section{Social Assistance in Sweden}

The Swedish welfare system is well known internationally for the high degree of income security that it provides for its citizens. Recently, this generous system has been the target of a number of reforms, mainly due to the recession that hit Sweden, and many other countries, in the early 1990's.

As an ultimate safety net, people in Sweden are covered by social assistance (SA). In order to be eligible for SA, all other welfare programs, such as housing allowance

\footnotetext{
${ }^{3}$ We define people as refugees if they were born in countries defined by the Swedish Immigration Board as refugee countries: Ethiopia, Afghanistan, Bulgaria, Bangladesh, Bosnia, Chile, Sri Lanka, Cuba, Iraq, Iran, India, Yugoslavia, China, Croatia, Lebanon, Moldavia, Peru, Pakistan, Poland, Russia, Soviet union,
} 
(bostadsbidrag), child allowance (barnbidrag), maintenance allowance (underhållsbidrag) and various pensions, must be exhausted first. The benefit levels vary, both across family types and regions, but are supposed to cover expenses essential for a "decent" living. To be eligible for SA benefits, a family must have income and assets below certain specified benefits levels (known as norms). The norms were, until 1998, determined in each of the 288 municipalities in Sweden. However, as of $1^{\text {st }}$ of January 1998, the regional variations in the norms were replaced by a national norm in order to reduce the inequality aspect of having differentiated norms. ${ }^{4}$ The norms serve as guidelines for the social worker who decides the actual size of the benefits. SA benefits are paid according to a schedule that sets a guarantee amount for a family of a given size. These benefits are reduced at a 100 percent reduction rate as the family's income rises.

Expenditures on social assistance have increased quite substantially in Sweden during the last 15 years. In Figure 2, we show total expenditures on SA from 1983 to 1998. During the 1980's total expenditures on welfare increased by over 30 percent. However, the most rapid increase in expenditures took place in the 1990's. Between 1990 and 1997, welfare costs increased by roughly 100 percent. In 1997, 12,4 billion SEK was spent on social assistance, or approximately 2 percent of all government expenditures.

Figure 2 also divides welfare expenditures separately for native Swedes and immigrants. It's quite clear that welfare expenditures increased at a much faster pace for immigrants than for native born Swedes between 1983 and 1998. Throughout the 1990's, immigrants and natives accounted for about the same amount of welfare expenditures.

Romania Somalia, Syria, Togo, Turkey, Ukraine, Uganda, Vietnam or if they were born in another subSaharan countries.

${ }^{4}$ According to the national norm in 1998, a single person would receive 2,884 SEK per month in SA while a couple with two children would receive about 7,500 SEK per month (depending on the age of the 
This is quite remarkable given that immigrants represent a 10 percent minority of the population in Sweden.

\section{Data}

\section{Description of the Data and Sampling Procedures.}

The data used in this paper is taken from a recently created Swedish longitudinal data set, Longitudinal Individual Data (LINDA). LINDA is a register-based data set and it consists of a large panel of individuals, and their household members, which are representative for the population from 1960 to 1996. LINDA is a joint endeavor between the Department of Economics at Uppsala University, The National Social Insurance Board (RFV), Statistics Sweden, and the Ministries of Finance and Labor. The main administrator of the data set is Statistics Sweden.

The primary sources for information in LINDA are the income registers (Inkomstoch Förmögenhetsstatistiken ) - available annually from 1968 to 1996 - and population census data (Folk- och Bostadsräkningen) - available every fifth year from 1960 to 1990. All variables in these registers are included in the data set. In addition, information from several other registers have been matched with these two core registers, such as information about educational attainments (obtained from Högskoleregistret (1977-1996) and Registret over komvuxstuderande (1985-1996)), pensions (obtained from the National Social Insurance Board), and unemployment (obtained from the Swedish Labor 
Market Board). Note that since LINDA is completely based on register information, there is essentially no attrition in the panel.

The sample used in this study consists of information from LINDA for the years 1990-1996. For these years, LINDA contains information on about 300,000 individuals annually (which corresponds to around 3 percent of the population). For each year, information on all household members of the sampled individuals is added to the data set. Since welfare participation in Sweden is based on household characteristics and household income, the appropriate unit of observation is the household. This means that the value of different observable characteristics, such as age and education, refers to the person in the household that was originally sampled. Furthermore, a household is defined as an immigrant household if the sampled person was born abroad, and as a refugee household if the person was born in a refugee country, as defined by the Swedish Immigration Board, or in a sub-Saharan country. If the household is defined as an immigrant or a refugee household, we have information about the year of arrival in Sweden. However, there are no immigrants arriving before 1968 included in LINDA. ${ }^{5}$

Attached to LINDA is a non-overlapping sample of immigrants created in the same fashion as the general sample. This immigrant sample consists of 20 percent of all individuals born abroad along with information about their families. In the empirical analysis, we merged the general LINDA sample with the additional immigrant sample.

\footnotetext{
${ }^{5}$ All immigrant households included in LINDA, whether defined as refugees or not, have obtained residence permits. This means for instance that asylum seekers who have not yet obtained a residence permit are not included in our sample.
} 
This generates a sample of the Swedish population where immigrants are overrepresented, but this can easily be adjusted for by using appropriate weights ${ }^{6}$.

\section{Variable Definitions and Descriptive Statistics}

To answer the three questions regarding immigrant assimilation and welfare participation raised in the introduction, we estimate two different relationships. In the first, the dependent variable is a binary variable equal to one if the household received SA for at least one month during the year, and equal to zero otherwise. In the second relationship, we use the information regarding the number of months the household received welfare as the dependent variable.

Using information provided by the Swedish municipalities, we were able to assign a social assistance norm (which determines the benefit level) to each household in the sample in 1994. These norms are determined by the municipality in which the household resides, as well as the household composition, such as marital status, age and number of children. Unfortunately, we have not been able to obtain similar information for the other years. For that reason, we were forced to assign the 1994 norms to every year. By including the norms into the models, we can obtain estimates of the effects of higher benefit levels on public assistance utilization. It also enables us to simulate the effects of a change in the benefit structure on both participation and spell lengths.

The effect of education on welfare utilization is determined by two binary variables describing the highest educational degree that the head of the household has

\footnotetext{
${ }^{6}$ The panel data set we created contained over 1.6 million observations. Due to the computationally intensive calculations required for the random effects probit estimated in this paper and the extremely large data set, we selected a 25 percent random sample of the total sample. This sub-sample was used for both the random effects probit model and the linear random effects model.
} 
obtained - high school or college. Hence, the excluded category in all estimations is less than high school.

About half of all foreign born residents in Sweden live in one of the three major cities in Sweden (Stockholm, Göteborg and Malmö), (Franzén, 1997). It is also well known that utilization of welfare is higher in large cities than in rural areas, perhaps due to a lower stigmatic effect. For these reasons, we include a control for residence of the households in a major city in our empirical models. This variable equals one if the household resides in any of the three largest cities, and it equals zero otherwise.

In Table 1, we present average characteristics for the household by welfare recipiency for the period 1990 to 1996. In general, we observe that households on welfare are younger, less educated and to a larger degree single, as compared to households not on public assistance. ${ }^{7}$ For immigrants, we observe that SA recipients have on average been in the country for a shorter period than those households off SA. Interestingly, refugee households have on average higher education compared to native Swedish and non-refugee immigrant households. Moreover, the fraction of college educated households receiving SA is substantially higher among refugees than among the other two groups. We also observe that number of children is similar regardless if a household is on welfare or not, and that refugee households have almost twice as many children as native Swedish households.

\footnotetext{
${ }^{7}$ Since participation in SA is based household characteristics, the entries in Table 1 refer to those of the household head.
} 


\section{Trends and Differences in Welfare Participation.}

As was shown in Figure 2, real expenditures on welfare increased substantially in Sweden during the 1990's. There are three possible reasons for the increases in expenditure: an increase in welfare participation, an increase in average welfare duration and/or an increase in the benefits level. Only the first two potential causes are to be studied in this paper. We feel that these are the most interesting ones from an empirical point of view. The reason for this is that the first two potential sources for the increase are related to household decisions and labor market conditions. The policymaker, however, determines the benefit level. ${ }^{8}$

There was a substantial increase in the number of households receiving SA over the period 1990 to 1996 . The National Board of Health and Welfare reports that 7.9 percent of all household in Sweden in 1990 received social assistance. This is shown in Table 2. By 1996, the participation rate had increased to 10.7 percent. This represents an increase by 35 percent. The table also shows that the average number of months on welfare increased over the period by the same percentage. The monthly amount received, however, increased by slightly less than 5 percent. It is quite clear that the increase in expenditures is mostly due to increases in participation rates and length of time on welfare.

Welfare participation rates have been shown to be different for immigrant and natives in many countries (see for example Borjas and Trejo, 1991; Maani, 1993 and Riphahn, 1998). Table 3 shows that this is true for Sweden as well. Both immigrants from

\footnotetext{
${ }^{8}$ It can, however, be argued that the individual can influence the benefit level by his actions and decisions, such as labor supply decisions.
} 
refugee and non-refugee countries are more likely to receive social assistance than native born Swedes. Furthermore, refugees participate to a greater extent in the social assistance program than non-refugees. This relative relationship also holds for the average number of months on welfare. Refugees stay on welfare longer than non-refugees while natives display the shortest period. The table also shows that the increases in all three measures over the period from 1990 to 1996 were greater for immigrants than they were for natives.

Did the increase in immigrant welfare participation stem from an increase in individuals' probability to participate in the social assistance program or is it due to a change in the composition of immigrants? Table 4 displays welfare measure by arrival cohorts. The native welfare participation rate increased by 1.5 percentage points from 1990 to 1996. No immigrant arrival cohort displays a greater increase in social assistance utilization rate than 1.25 percentage points. In other words, all arrival cohorts decreased their welfare participation rates relative to natives. In fact, 3 out the four non-refugee arrival cohort display decreased welfare probabilities in an absolute sense. This is also true for the refugee 1986-90 arrival cohort. It appears that the observed overall increase in immigrant participation rates is due to a change in the composition of immigrants. The increase in immigration combined with the observation that newly arrived immigrants are more likely to participate in the social assistance program, seem to be the cause for the greater than native increase in overall immigrant welfare participation rates.

The above pattern suggests that immigrants assimilate out-of the welfare dependence. As can be seen in Table 4, there is substantial variation in participation rates for both non-refugees and for refugees depending on arrival year. Immigrants arriving 
between 1968 and 1975 have significantly lower participation rates compared to later arrival cohorts. Welfare participation rates appear to increase monotonically with arrival year. The same pattern can be found both in 1990 and in 1996. One possible reason for the higher welfare dependency rates among more recent arrival cohorts is a decline in the skill level of later cohorts, i.e. negative cohort effects. In a series of articles, Borjas (e.g. 1985 and 1994b) has shown that such cohort effects can cause overestimated assimilation rates of immigrants. However, this does not seem to be the case in Sweden. Since for any given arrival cohort, the welfare utilization rate decreases relative to natives over the period studied here. Negative cohort effects appear to be less pronounced, if they exist at all, among the immigrant population in Sweden. Immigrants seem to assimilate in the sense of reducing their social assistance participation rates to levels approaching those of native born individuals with time spent in Sweden.

Another reason for the increase in welfare expenditures is that there has been an increase in the length of social assistance spells. In Table 4, we also show the average number of months on social assistance, conditional on being on welfare. In general we observe similar assimilation patterns for the length of welfare spells as we do for SA participation. That is, immigrants belonging to early arrival cohorts experience, on average, shorter durations on SA. However, when studying the change in months on public assistance between 1990 and 1996, we see that most of the increase that we observed in Table 3 is due to an increase among all arrival cohorts, and not solely due to an increase among more recent immigrants.

Immigrant assimilation out-of welfare becomes quite clear when the difference in participation rates and average welfare spells between immigrants and natives are shown 
by years since migration, as in Figure 3 and 4 . Refugees in particular seem to assimilate quickly. Their initial welfare participation rates are between 40 and 50 percent higher than natives. After 10-11 years in Sweden, the difference drops to about 10 percent. Nonrefugee immigrants also appear to assimilate out-of welfare. Figure 4 suggests that welfare dependency in terms of months per year on social assistance, relative to the native population, also decreases rapidly with years spent in Sweden. It should be noted that these comparisons are flawed in several ways. For example, the average age of natives is held roughly constant while the average age of the immigrant population increases with years since migration. Also, even though cohort effects do not appear to be strong in Sweden, they need to be incorporated into the analysis. Differences between immigrants and natives, or changes in differences over time, in socioeconomic and geographic characteristics may also partly explain the pattern. To accurately analyze assimilation rates, an empirical model needs to be estimated. We now turn our attention to such a model.

\section{Empirical Specification and Results}

To analyze welfare utilization we need insight to why households participate in social assistance. Clearly, the labor market conditions household members faces will affect the probability that the household will end up on welfare. In other words, the factors we believe will affect employment probabilities also need to be incorporated into our welfare utilization models. It is also quite plausible that immigrants and natives do not face the same labor market conditions. For example, human capital obtained abroad may be viewed differently than human capital acquired in the new country. 
Discrimination of immigrants is another possibility. It is therefore important to allow the employment factors to affect welfare participation probabilities differently for immigrants and natives. Individuals' preferences and tastes for leisure will also affect the probability of being on welfare through differences in the reservation wages. The so called stigma effect of receiving welfare payments also depends on individuals' preferences. The individual differences in reservation wages and the potential stigma of being on welfare are inherently unobservable but can be controlled for by using estimation methods that allow for differences across individuals, i.e. random or fixed effects. However, before we incorporate unobserved heterogeneity we want to analyze the role of observable characteristics on welfare utilization. We turn to this next.

\section{Do Differences in Observable Characteristics Explain Differences in Welfare Participation?}

To answer the question that we raised in the introduction, whether the overrepresentation of immigrants among welfare recipient households is due to differences in observable characteristics or if it is due to behavioral differences or differences in labor market conditions, we formulate a probit model of welfare participation and an ordinary linear squares model of months on welfare, conditional on being a welfare recipient. The models control for age, educational attainment, marital status, number of children and whether the household is located in one of the 3 major cities in Sweden. This set of control variables is very similar to what has been used in previous studies for other countries. The models also include indicator variables for non-refugee and refugee immigrants, in addition to a variable for Nordic immigrants. If higher welfare participation rates and longer social assistance spells are simply due to differences in 
these characteristics between natives and immigrants, the estimated coefficients on the immigrant variables should not be significantly different from zero. The results are presented in Tables 5 and 6.

All immigrants appear to be more likely to participate in the social assistance program even after observable characteristics are controlled for. Model 1 shows the differences in probability of receiving welfare between the 3 immigrant categories and natives, adjusting for the national trend over the period ${ }^{9}$. The overall difference between non-refugee immigrants and natives is 6.3 percentage points. The probability that a Nordic immigrant household participates in the social assistance program appears be no different from a non-refugee immigrant's household. A refugee household is substantially more likely to be on welfare than a native household, the difference is about 20.7 percentage points. The results for Model 2 indicate that differences in observable characteristics explain very little of the differences in welfare participation between natives and immigrants. Immigrants from non-refugee countries are about 5.9 percentage points more likely to receive welfare compared to statistically similar natives. Only 6 percent of the total observed difference, is due differences in observable characteristics. Model 2 also indicates that Nordic immigrants are less likely than non-refugee immigrants to be on social assistance, by about 0.7 percentage points. The estimated difference for a refugee household drops by 2 percentage points when the observable socioeconomic variables are included in the model. A very small proportion, roughly 10

\footnotetext{
${ }^{9}$ Note that the difference in probability of welfare participation between Nordic immigrants and natives is the sum of the non-refugee and Nordic country estimated coefficients. Similarly, the disparity between immigrants from refugee countries and natives is the sum of the two estimated coefficients for non-refugees and refugees.
} 
percent, of the higher observed participation rates of refugees can be explained by differences in age, education, household composition and geographic location.

Immigrants also stay on welfare for longer periods than natives. Model 1 in Table 6 shows that on average the differences are approximately 1 month for non-refugees, 2.7 months for refugees and half a month for Nordic immigrants. When the model includes controls for observable characteristics, as Model 2 does in Table 6, these differences drop to $0.8,2.4$ and 0.25 months for non-refugees, refugees and Nordic immigrants respectively. A substantial share of the differences in the number of months on social assistance remains even after the variables in Model 2 are included.

We showed in Table 4 that it is important to allow for differences in welfare utilization between arrival cohorts. To ensure that changes in the composition of immigrants over the period does not explain the large differences even after observables have been controlled for, we re-estimated Models 2 in Table 5 and 6 with arrival cohort dummies. The results are shown in Tables 5 and 6 as Models 3. The differences between immigrants and natives remain essentially as large, or larger, as when controls for arrival cohorts were not included. It is quite clear that differences in both welfare participation and differences in the length of welfare spells between immigrants and natives are not due to differences in socioeconomic characteristics.

Our findings that differences in observable characteristics between immigrants and natives do not explain the higher welfare participation rates of immigrants differ from the findings for the U.S., Canada, Australia and Germany. The analysis performed here does not tell us whether the differences between immigrants and natives are due to behavioral differences or differences in labor market opportunities between the two 
groups. There may be two possible reasons for the differences in findings across countries. First, the Swedish labor market may view immigrants and their observable characteristics differently from the above mentioned countries' labor markets. Another possible reason is that immigrants do not randomly choose the destination country. Instead, they may self-select according to preferences, relative expected earnings and the generosity of the welfare system in the new host country. If so, immigrants may select Sweden partially due to its very generous welfare system. It should be noted that our analysis does not allow us to determine the extent to which each of the above mentioned reasons contribute to the discrepancy in findings across countries.

\section{Assimilation Into or Out-of Welfare?}

As discussed above, it is important to control for unobserved effects when estimating welfare participation functions. To account for unobserved heterogeneity, we estimate a random effects probit model of social assistance participation. To ensure that our results are not specific to the random effects assumptions, we also estimated a fixed effects logit model. We were concerned about the assumption made in the random effects model that the household specific error terms are uncorrelated with the observed independent variables. The assimilation results derived from the fixed effects logit model are remarkably similar to the random effects probit results. For that reason and because the effects of the time invariant variables are of interest in a study like this, we only report the random effects probit results.

To be as flexible as possible, and to allow for different effects of observable variables for native Swedish households and immigrant households (both refugee and 
non-refugee), we specify a fully interacted model, where all the observable variables are interacted with indicator variables for immigrants and refugees. In order to assess whether immigrants assimilate into or out-of welfare dependency, we incorporate information about years since migration. We also know from Section 2 that the composition of immigrants has changed substantially over the last 30 years, and it is therefore important to control for differences in arrival cohorts. This is accomplished by the inclusion of four additional binary variables indicating time of arrival to Sweden.

To estimate the parameters in the model we need to make additional assumptions. Specifically, we assume that the stochastic terms can be decomposed into two parts: one unobserved household specific effect (which is time invariant) and one white-noise error term that varies both across households and time periods. We further assume that these two error components are drawn from two independent normal distributions with mean zero and constant variances. This yields a random effects probit model which is not only able to capture effects of unobservable variables but also accounts for the fact that the panel is unbalanced. To be specific, the model can be described as follows. Let

$$
y_{i t}^{*}=\mathbf{X}_{i t} \beta+\mathbf{Y S M}_{i t} \delta+\mathbf{A g e}_{i t} \gamma+\varepsilon_{i t} \quad \forall i=1,2, \ldots, n \text { and } t=1,2, \ldots, T_{\mathrm{i}}
$$

where,

$$
\varepsilon_{i t}=\mu_{i}+v_{i t}
$$

$y_{i t}^{*}$ is a latent variable representing preferences for welfare utilization of household $i$ at time $t . \mathbf{X}$ is a vector of socio-economic and geographic characteristics, including arrival cohort, educational attainment, marital status, number of children and whether the household is located in one of the 3 major cities in Sweden. In addition, it includes a variable containing information about the prevailing social assistance norm where the 
household resides. Age is a vector of age variables, i.e. age and $\operatorname{age}^{2}$, and YSM is a vector of years since migration variables, i.e. YSM and YSM ${ }^{2}$. The vectors $\mathbf{X}$, Age and YSM are all fully interacted with two indicator variables for non-refugee and refugee immigrants. $\mu_{i}$ is an unobserved household specific effect and $v_{i t}$ is a white-noise error term. We assume that these unobserved stochastic terms have the following properties:

$$
\mu_{i}, v_{i t} \sim N(0, \Omega)
$$

with

$$
\Omega=\left[\begin{array}{cc}
\sigma_{\mu}^{2} & 0 \\
0 & 1
\end{array}\right]
$$

This implies that

$$
\operatorname{Var}\left(\varepsilon_{i t}\right)=\sigma_{\mu}^{2}+1
$$

and

$$
\operatorname{Corr}\left(\varepsilon_{i t}, \varepsilon_{i s}\right)=\rho=\frac{\sigma_{\mu}^{2}}{\sigma_{\mu}^{2}+1}
$$

We do not observe $y^{*}$, but we assume that we can observe the sign of it, and based on that we can formulate the following decision rule:

$$
y_{i t}=1 \text { if } y_{i t}^{*}>0, \text { and } 0 \text { otherwise }
$$

where $y_{i t}=1$ represents utilization of SA. The household's contribution to the likelihood function can be written as:

$$
L_{i}=\frac{1}{\sqrt{\pi}} \int_{-\infty}^{\infty} e^{-\mu_{i}^{2}}\left\{\prod_{t=1}^{T_{i}} \Phi\left[q_{i t}\left(\mathbf{z}_{i t} \lambda+\sqrt{\frac{2 \rho}{1-\rho}} \mu_{i}\right)\right]\right\} d \mu_{i}
$$

where:

$$
\mathbf{z}_{i t} \lambda=\mathbf{X}_{i t} \beta+\mathbf{Y S M}_{i t} \boldsymbol{\delta}+\mathbf{A g e}_{i t} \gamma
$$


and

$$
q_{i t}=2 y_{i t}-1
$$

The sample likelihood is simply the product of the above probabilities across households.

\section{Welfare Participation}

The results from the model described above can be found in Table 7. In the first two columns, we present the results for native Swedes, while columns 3 and 4 present the results for immigrants from non-refugee countries. Finally, the last two columns show the results for refugees. Note that to obtain marginal effects for non-refugee immigrants, it is necessary to add the estimated marginal effects for natives, shown in column 2 , to the effect specific to immigrants, as shown in column 4. Similarly, to get the marginal effects for immigrants from refugee countries, it is necessary to add the shown effects in column 2,4 and 6.

The estimates of the time effects shows that there has been a significant increase in welfare participation between 1990 and 1996 for both native Swedes and immigrants, even after controlling for both observed and unobserved household effects. The increase is largest for refugee households, whose participation rates increased by over 5 percentage points during this period. For both non-refugee immigrants and native Swedes the increase was 2 percentage points. Moreover, for native Swedish and non-refugee households, participation in social assistance has experienced some variation during the first half of the 1990's, with peaks in 1993 and 1996. For refugee households we observe a monotonic increase in social assistance participation between 1990 and 1996. This result may indicate that the utilization of welfare among refugee households is sensitive 
towards the situation in the labor market. During the early 1990's, unemployment rates increased from about 2.5 percent in 1990 to about 9 percent in 1996. One possibility is that the sharp tightness in the labor market affected welfare utilization among refugee households to a larger extent than the utilization among other households (Mossler, 1998). Another reason for the monotonic increase in participation between 1990 and 1996 is the substantial increase in the number of refugees arriving in 1993 and 1994. Most of these refugees became entitled to social assistance between 1994 and 1995. Regarding the effect of the household head's age, the entries in Table 7 indicates a concave relationship between age and welfare participation. That is, participation increases with age but at a decreasing rate. This appears to hold for all three groups, natives, non-refugee immigrants and refugee immigrants.

Not surprisingly, education has a strong and significant effect on welfare participation. For instance, for native Swedes the difference in expected participation between households where the head has less than a high school degree and those households where the head's highest education is a high school degree (or equivalent) is close to 2 percentage points. For those native households where the head has a college degree, the difference in expected welfare probability is even larger, over 8 percentage points. This reveals a clear pay-off to education in terms of reducing the risk of ending up on welfare. For non-refugee households we find a similar pattern between education and welfare participation, although the differences are not as large as for native Swedish households. Perhaps a bit surprising, we find no support for a significant negative effect of a high school degree on welfare participation among refugee households. Refugee households where the household head has a college degree are 4 percentage points less 
likely to be on public assistance compared to refugee households where the household head has only completed grade school. The negative impact on the participation probability of a college degree is only about one half of the impact on natives. One possible reason for this relationship may be that education acquired abroad is not as highly recognized by native employers, as is education obtained in the host country. One indication of this relationship is that returns to pre-migration education have been found to be lower than both post-migration education and natives' education (Betts and Lofstrom, 1999).

Concerning the effects of the household composition on welfare participation, we observe that married households have a significantly lower probability of receiving welfare than single households. This is especially true for natives, where the probability for a married household to receive welfare is about 9 percentage points lower than for a single household. For immigrant households (both non-refugee and refugee), we observe a similar pattern, although the effect is smaller. Household size, in terms of number of children, has no significant effect on welfare participation for native Swedish households, while it has a positive but not significant effect for immigrant households.

An interesting result is that the effect of the social assistance norm is positive and significant, implying that, everything else held constant, welfare participation rates are higher in municipalities where the norm is relatively high. We will analyze this in more detail in the next Section where we simulate the impact of an actual and substantial reform in the benefit levels.

One of the main purposes of this paper is to study whether immigrants assimilate into or out-of welfare dependency. The estimated coefficients for the age and years since 
migration vectors can be used to trace out differences in the probability of welfare receipiency between immigrants and natives by years since migration. It is also necessary to choose values for the characteristics included in the matrix X. We have chosen 1996 as our baseline year and a household with the following characteristics: married with one child, located in one of the major cities and the head is a high school graduate. These choices represent the mode for these variables. The predicted differences in welfare participation between immigrants and natives, calculated for the representative household described above, are shown in Figures 5, 6 and 7.

The figures indicate that immigrants assimilate out-of welfare with time spent in Sweden. Figure 5 shows that both non-refugee and refugee households reduce their utilization of welfare, relative to natives with years since migration. In particular, the assimilation process is substantially faster for refugee households. Despite much higher initial participation rates than non-refugee households, after 14-15 years the difference in participation rates between native and refugee households is smaller than the difference between native and non-refugee households. However, it should be noted that neither group appear to reach the participation rates of native households within a 20 year period in Sweden. ${ }^{10}$

It was shown in Section 2 that the composition of immigrants has changed substantially over the last 30 years. It is therefore important to control for arrival cohorts. Figures 6 and 7 show differences in welfare participation between natives and immigrants by arrival cohorts. The trends in Figure 6 indicate that there are quite small differences in

\footnotetext{
${ }^{10}$ The figures show differences in participation rates assuming that age at migration is equal to 18 . To assess the impact of age at migration, we re-created Figure 5 setting age at migration to 30. Our findings suggest that age at migration has a very minor impact on non-refugee immigrants' participation behavior. Refugee immigrants, however, display slightly slower assimilation rates the older the immigrant is upon
} 
the predicted assimilation patterns between arrival cohorts. Non-refugee immigrants arriving between 1991 and 1996 have no higher participation rates than non-refugee immigrants who arrived between 1968 and 1975. Figure 7 shows a similar pattern for refugee households. In fact, our results indicate that the latest arrival cohort have lower participation rates than the earliest arrival cohort of refugee immigrants.

To summarize our results concerning immigrant assimilation in welfare utilization, we find strong support for the hypothesis that immigrant households in Sweden tend to assimilate out-of rather than into welfare dependency. This result differs from the results found in the existing literature on the welfare assimilation of immigrants. However, even after 20 years in the host country we find that both refugee and nonrefugee immigrants show significantly higher social assistance participation rates than statistically similar natives by between 5 and 7 percentage points. Remarkably, this is slightly lower than what is found in Borjas and Hilton (1996), using U.S. data, and Baker and Benjamin (1995), using Canadian data, whose estimates imply differences of around 12 and 8 percentage points respectively. ${ }^{11}$ This finding suggests that immigrants in an extremely generous welfare state, like Sweden, display similar welfare participation behavior as immigrants in less generous welfare states, like the U.S. and Canada, relative to natives after having spent some time in the new host country. Finally, our results indicate that more recent immigrants are no more prone to rely on welfare than immigrants who arrived earlier.

arrival to Sweden. We also estimated models including explicit controls for age at migration and found no differences to the findings reported in the paper.

${ }^{11}$ We used the estimated coefficients that Borjas and Hilton report in Table 7 and the ones Baker and Benjamin report in Table 2 to calculate the predicted differences in participation rates. The predictions 


\section{Months on welfare}

When analyzing welfare dependency, we are not only interested in welfare participation but also in the duration of welfare for those who receive it. In order to assess immigrant assimilation in this respect, we estimate a standard random effects model, where the dependent variable is months on welfare. The model is fully interacted and contains the same variables as the one estimated for welfare participation. The results can be found in Table 8. In the first column, we present the results for native Swedes, while columns 2 and 3 presents the results for immigrants from non-refugee countries, and the last two columns shows the results for refugees.

Concerning the effects of most of the observable variables that are included in the model, we find a pattern that is very similar to what we found for welfare participation. That is, a significant and large increase in months on welfare from 1990 to 1996 for all groups, especially for refugee households, even after controlling for a detailed set of observable variables. Further, months on welfare increase with age but at a decreasing rate except. This holds true for both natives and non-refugee immigrants. The pattern is opposite for refugee households, where the length of social assistance spells decreases with age. Higher education and marriage implies shorter welfare durations while living in one of the 3 major cities in Sweden has the opposite effect. This holds true for all three groups, with one possible exception. Marriage does not seem to affect the number of months refugees receive public assistance. However, unlike the results for welfare participation, we find that benefit levels have no significant effect on months on welfare. 
The way immigrants assimilate in terms of months on welfare is shown in Figures 8,9 and 10. Interestingly, the patterns in these figures are very similar to the ones observed for welfare participation, shown in Figures 5, 6 and 7. That is, the longer an immigrant household stays in Sweden, the shorter time will they spend on welfare. We find that more recent immigrants stay longer on welfare than earlier immigrant arrival cohorts. However, the differences between cohorts are relatively small. Finally, we find that refugee households tend to assimilate much faster than non-refugee households, as was the case for welfare participation, but that no parity is reached between immigrants and natives.

\section{Simulation of Impact of Changes in Social Assistance Norm.}

In the Swedish welfare system, a family with income and assets below certain specified levels is eligible for social assistance benefits. These levels, known as norms, were until 1998 determined in each of the 288 municipalities in Sweden. The norms differed substantially across municipalities. For example, for a single person without dependents, the compensation varied between 1,613 and 4,107 SEK per month, depending on which municipality the person resided in. This implies that a person living in a municipality paying the lowest benefits only received 39 percent of the benefits a similar person living in a municipality paying the highest benefits received. When we consider other family types, the difference is even greater.

In January 1998, the regional variations in the norms were replaced by a national uniform norm. It was argued that the old system with considerable differences in the 
benefit levels was unfair, and that a nationally uniform benefit structure is more appropriate. To exemplify the effects of the introduction of the reform, according to the national norm in 1998, a single person without dependents would receive 2,884 SEK per month in social assistance. This figure is very close to the average value of the norm that prevailed before the reform. Hence, the old system of large variations in norms was essentially replaced by national averages. The reform implied large increases in expenditures on social assistance for those municipalities that had a norm below the national average, and vice versa for municipalities with higher than average norms. ${ }^{12}$ However, there exists no common conception about the overall effects of the reform on welfare expenditures for the country. We now turn to a simulation of the reform based on our estimates in Table 7.

To evaluate how the reform in the benefit structure might affect welfare participation and total welfare expenditures, we predicted welfare participation rates under both the old regime with local variations in the levels and under the new uniform regime. Since our results indicate that the norm does not affect the number of months recipients receive welfare, we only simulate the impact of the change on welfare participation. Our calculations indicate that the reform lowered the benefit level to the same extent for both natives and immigrants. On average the norm was reduced by 831 SEK, from 5,620 SEK per month to 4,781 SEK. The simulation results are shown in Table 9.

All groups, both natives and immigrants, appear to be less likely to participate in the social assistance program after the reform is implemented. Overall, the reform implies

\footnotetext{
${ }^{12}$ It should be noted that the local authorities might still set their norms somewhat higher than the national norm.
} 
a reduction in welfare participation by about half a percentage point, or a decrease by slightly more than 5 percent. However, the effects of the reform vary across natives and immigrants. For natives and refugees, the effects are largest with a reduction of about 6 percent, while for non-refugee immigrants the reduction is smaller, 3.3 percent. A backof-the-envelope calculation of the overall effects on total expenditures on social assistance from the reform indicates a reduction of almost 700 million SEK. ${ }^{13}$

\section{Conclusion and Summary}

This paper analyzes differences in welfare utilization between immigrants and natives in Sweden using a large panel data set, LINDA, for the years 1990 to 1996 . Welfare expenditure in Sweden, as with many western countries, increased substantially in the 1990's. Closely linked to the increase in welfare costs in Sweden is an increase in immigration. In this paper we find that immigrants use welfare to a greater extent than natives. Furthermore, non-refugee immigrants utilize social assistance less than refugee immigrants. Differences in welfare participation and number of months on welfare between immigrants and natives cannot be explained by observable socioeconomic characteristics.

Immigrants appear to lower their participation rates in welfare with time spent in Sweden in both an absolute sense, as well as relative to natives. Although, refugees display substantially higher public assistance participation rates upon arrival in Sweden compared to non-refugee immigrants, they assimilate out-of welfare at a faster rate than

\footnotetext{
${ }^{13}$ When calculating the effect on total expenditures, we have kept months on welfare constant since the estimates of the social assistance norm were not significant at conventional levels.
} 
non-refugee immigrants. However, it should be noted that neither group is predicted to reach the participation rates of native households within a 20 year period in Sweden. Our estimated results indicate that there are only relatively small differences in participation rates between arrival cohorts. The predicted differences in the length of social assistance spells follow a very similar pattern.

We also simulate the impact of the 1998 welfare reform that introduced a nationally unified benefits structure. Overall, participation rates decreased by more than 5 percent. This implies a reduction in welfare expenditures by about 700 million SEK, or close to 6 percent of the 1997 total welfare costs in Sweden. Interestingly, in 1998, the year of the reform, welfare costs decreased for the first time in Sweden in the 1990's. The decrease, which was around 8 percent, is quite close to our back-of-the-envelope calculations of the impact of the reform on welfare utilization. However, part of the decrease in welfare costs is quite likely due to the slightly improved economic conditions in Sweden during this period.

Immigration has been at the heart of welfare debates in many countries in the 1990's. Due to the continued increase in immigration in many countries such as the U.S., Germany and Sweden, this is unlikely to change anytime soon. Given the rapid decrease in welfare utilization of immigrants, particularly refugees, with time spent in the new country, the welfare cost upon arrival should not be used to make long-term prediction of welfare costs caused by immigration. However, immigrants are over-represented among the welfare population even after observable characteristics are controlled for. This suggests that in future research it is important to analyze why this is the case. One question that arises is: Are immigrants' observable skills not recognized to the same 
extent as natives' skills in the Swedish labor market or do immigrants have higher reservation wages? 


\section{References}

Baker, Michael, and Dwayne Benjamin, The Receipt of Transfer Payments by Immigrants to Canada, Journal of Human Resources, 30(4), 1995, 650-676.

Bean, Frank D., Van Hook, Jennifer V.W. and Glick, Jennifer E. "Country of Origin, Type of Public Assistance, and Patterns of Welfare Recipiency among U.S. Immigrants and Natives," Social Science Quarterly, 78(2), 1997, 432-51.

Betts, Julian R. and Lofstrom, Magnus "The Educational Attainment of Immigrants: Trends and Implications," in Issues in the Economics of Immigration, Eds George J. Borjas, University of Chicago Press, 1999.

Blau, Francine D. "The Use of Transfer Payments by Immigrants," Industrial and Labor Relations Review, January 1984, 2, 222-39.

Borjas, George J. "Assimilation Changes in Cohort Quality and the Earnings of Immigrants," Journal of Labor Economics, October. 1985, 4, 463-89.

Borjas, George J. Friends or Strangers: The Impact of Immigrants on the U.S. Economy. New York: Basic Books, 1990.

Borjas, George J. "Immigration and Welfare," NBER Working Paper No. 4872, September 1994a.

Borjas, George J. "The Economics of Immigration," Journal of Economic Literature, December 1994b, 32, 1667-717.

Borjas, George J. and Trejo, Stephen J. "Immigrant Participation in the Welfare System," Industrial and Labor Relations Review, January 1991, 2, 195-211.

Borjas, George J. and Trejo, Stephen J. "National Origin and Immigrant Welfare Recipiency", Journal of Public Economics , 50(3), 1993, 325-344.

Borjas, George J. and Hilton, Lynette, "Immigration and the Welfare State: Immigrant Participation in means-tested Entitlement Programs", Quarterly Journal of Economics 111(2), 1996, 575-604.

Franzén, Eva, "Invandrare och Socialbidrag," Socialvetenskaplig Tidskrift, 4, 1997, 279304.

Hu, Wei-Yin, "Elderly Immigrants on Welfare," Journal of Human Resources, 33(3), Summer 1998, 711-41. 
Maani, S.A. "Immigrants and the Use of Government Transfer Payments", Australian Economic Review, 0(104) Oct.-Dec. 1993, 65-76.

Mossler, Karin, “Allt fler har långvarigt socialbidrag,“ VälfärdsBulletinen, 1998, 4-6.

Riphanh, Regina T. "Immigrant Participation in Social Assistance Programs: Evidence from German Guestworkers,” IZA Discussion Paper No. 15, July 1998.

Zimmermann, Klaus F. "Tackling the European Migration Problem," The Journal of Economic Perspectives, (9)2, 1995, 45-62. 
Table 1.

Mean Observable Characteristics by Immigrant Status and Welfare Receipt.

\begin{tabular}{|c|c|c|c|c|c|c|}
\hline & \multirow{2}{*}{\multicolumn{2}{|c|}{ Natives }} & \multicolumn{4}{|c|}{ Immigrants } \\
\hline & & & Non-Refug & ee Country & Refugee Cc & untry \\
\hline & $\begin{array}{c}\text { Non-Welfare } \\
\text { Recipient } \\
\end{array}$ & $\begin{array}{c}\text { Welfare } \\
\text { Recipient } \\
\end{array}$ & $\begin{array}{c}\text { Non-Welfare } \\
\text { Recipient } \\
\end{array}$ & $\begin{array}{c}\text { Welfare } \\
\text { Recipient } \\
\end{array}$ & $\begin{array}{c}\text { Non-Welfare } \\
\text { Recipient } \\
\end{array}$ & $\begin{array}{c}\text { Welfare } \\
\text { Recipient } \\
\end{array}$ \\
\hline Age & 40.46 & 32.31 & 39.31 & 35.08 & 35.91 & 34.54 \\
\hline $\begin{array}{l}\text { Years Since Migration } \\
\text { Education }\end{array}$ & $\mathrm{N} / \mathrm{A}$ & $\mathrm{N} / \mathrm{A}$ & 15.87 & 13.34 & 9.63 & 5.37 \\
\hline Elementary School & $31.34 \%$ & $43.54 \%$ & $36.29 \%$ & $47.31 \%$ & $38.61 \%$ & $45.97 \%$ \\
\hline High School & $58.22 \%$ & $54.65 \%$ & $51.99 \%$ & $48.56 \%$ & $47.93 \%$ & $44.57 \%$ \\
\hline College & $10.43 \%$ & $1.81 \%$ & $11.73 \%$ & $4.13 \%$ & $13.46 \%$ & $9.46 \%$ \\
\hline Married & $48.02 \%$ & $10.53 \%$ & $48.26 \%$ & $19.96 \%$ & $58.21 \%$ & $44.33 \%$ \\
\hline Number of Children & 0.57 & 0.52 & 0.71 & 0.70 & 0.99 & 1.01 \\
\hline Sample Size: & $1,009,780$ & 44,372 & 304,239 & 33,125 & 183,162 & 72,712 \\
\hline
\end{tabular}

Source: Longitudinal Individual Data for Sweden (LINDA), 1990 to 1996.

Table 2.

Welfare Measures, 1990 and 1996.

\begin{tabular}{lrrr}
\hline & \multicolumn{2}{c}{ Year } & \multicolumn{1}{c}{ Difference } \\
& 1990 & 1996 & $1990-1996$ \\
\hline Welfare Participation. & & & 2.80 \\
Average Number of Months on Welfare & 4.1 & 5.5 & 1.4 \\
Average Real Monthly Amount (1996 SEK) & 5113 & 5359 & 247 \\
\hline Source: The National Board of Health and Welfare Social Assistance 1998.
\end{tabular}

Source: The National Board of Health and Welfare. Social Assistance 1998. 
Table 3.

Welfare Measures by Immigrant Status, 1990 and 1996.

\begin{tabular}{|c|c|c|c|}
\hline & \multicolumn{2}{|c|}{ Year } & \multirow{2}{*}{$\begin{array}{l}\text { Difference } \\
1990-1996 \\
\end{array}$} \\
\hline & 1990 & 1996 & \\
\hline \multicolumn{4}{|c|}{ Welfare Participation } \\
\hline Natives & $3.18 \%$ & $4.68 \%$ & 1.50 \\
\hline \multicolumn{4}{|l|}{ Immigrants } \\
\hline Non-Refugee Country & $8.29 \%$ & $10.15 \%$ & 1.86 \\
\hline Refugee Country & $16.49 \%$ & $31.99 \%$ & 15.50 \\
\hline \multicolumn{4}{|c|}{ Average Number of Months on Welfare } \\
\hline $\begin{array}{l}\text { Natives } \\
\text { Immigrants }\end{array}$ & \multicolumn{2}{|c|}{ Immigrants } & 1.00 \\
\hline Non-Refugee Country & 4.14 & 5.70 & 1.56 \\
\hline Refugee Country & 5.74 & 7.84 & 2.10 \\
\hline \multicolumn{4}{|c|}{ Average Real Monthly Amount (1996 SEK) } \\
\hline $\begin{array}{l}\text { Natives } \\
\text { Immigrants }\end{array}$ & 3,708 & 3,986 & 279 \\
\hline Non-Refugee Country & 3,944 & 4,609 & 665 \\
\hline Refugee Country & 5,350 & 6,781 & 1,432 \\
\hline
\end{tabular}


Table 4.

Welfare Measures by Immigrant Status and Arrival Cohort, 1990 and 1996.

\begin{tabular}{|c|c|c|c|c|c|c|c|c|}
\hline & \multicolumn{2}{|c|}{ Sample Size } & \multicolumn{3}{|c|}{ Welfare Partcipation Rates } & \multicolumn{3}{|c|}{ Months on Welfare } \\
\hline & 1990 & 1996 & 1990 & 1996 & 1990-1996 & 1990 & 1996 & $\begin{array}{l}\text { Dimerence } \\
1990-1996 \\
\end{array}$ \\
\hline Natives & 147,319 & 151,096 & $3.18 \%$ & $4.68 \%$ & 1.50 & 3.69 & 4.68 & 1.00 \\
\hline \multicolumn{9}{|l|}{ Immigrants } \\
\hline \multicolumn{9}{|c|}{ Non-Refugee Country } \\
\hline 1968-75 & 19,011 & 22,557 & $7.01 \%$ & $6.64 \%$ & -0.38 & 3.95 & 5.12 & 1.17 \\
\hline $1976-80$ & 6,200 & 10,595 & $8.90 \%$ & $10.01 \%$ & 1.10 & 4.15 & 5.36 & 1.21 \\
\hline $1981-85$ & 3,405 & 6,005 & $11.34 \%$ & $10.99 \%$ & -0.35 & 4.16 & 5.32 & 1.16 \\
\hline $1986-90$ & 1,803 & 8,422 & $13.92 \%$ & $13.58 \%$ & -0.34 & 5.08 & 5.91 & 0.84 \\
\hline $1991-96$ & & 6,069 & & $17.85 \%$ & & & 6.85 & \\
\hline \multicolumn{9}{|c|}{ Refugee Country } \\
\hline 1968-75 & 2,536 & 3,330 & $7.85 \%$ & $9.10 \%$ & 1.25 & 4.26 & 5.53 & 1.27 \\
\hline $1976-80$ & 4,121 & 6,458 & $11.65 \%$ & $11.66 \%$ & 0.01 & 4.58 & 5.77 & 1.20 \\
\hline $1981-85$ & 4,094 & 6,818 & $16.17 \%$ & $16.46 \%$ & 0.29 & 5.19 & 6.20 & 1.00 \\
\hline $1986-90$ & 2,304 & 16,009 & $35.24 \%$ & $30.06 \%$ & -5.18 & 7.24 & 7.07 & -0.17 \\
\hline $1991-96$ & & 20,480 & & $48.80 \%$ & & & 8.62 & \\
\hline
\end{tabular}

Source: Longitudinal Individual Data for Sweden (LINDA), 1990 and 1996. 
Table 5.

Probit Models of Welfare Participation.

Note: Standard errors appear in parentheses. Data are from Longitudinal Individual Data for Sweden (LINDA), 1990 to 1996.

\begin{tabular}{|c|c|c|c|c|c|c|}
\hline \multirow[b]{2}{*}{ Variable: } & \multicolumn{2}{|c|}{ Model 1} & \multicolumn{2}{|c|}{ Model 2} & \multicolumn{2}{|c|}{ Model 3} \\
\hline & $\begin{array}{l}\text { Estimated } \\
\text { Coefficient } \\
\end{array}$ & $\begin{array}{c}\text { Marginal } \\
\text { Effect } \\
\end{array}$ & $\begin{array}{l}\text { Estimated } \\
\text { Coefficient } \\
\end{array}$ & $\begin{array}{c}\text { Marginal } \\
\text { Effect }\end{array}$ & $\begin{array}{l}\text { Estimated } \\
\text { Coefficient } \\
\end{array}$ & $\begin{array}{c}\text { Marginal } \\
\text { Effect } \\
\end{array}$ \\
\hline Constant & $\begin{array}{r}-1.8889 \\
(0.0106)\end{array}$ & & $\begin{array}{r}-1.7677 \\
(0.0447)\end{array}$ & & $\begin{array}{r}-1.7004 \\
(0.0454)\end{array}$ & \\
\hline 1991 Year Effect & $\begin{array}{r}0.0879 \\
(0.0133)\end{array}$ & 0.0125 & $\begin{array}{r}0.0907 \\
(0.0140)\end{array}$ & 0.0107 & $\begin{array}{r}0.0682 \\
(0.0139)\end{array}$ & 0.0077 \\
\hline 1992 Year Effect & $\begin{array}{r}0.1117 \\
(0.0132)\end{array}$ & 0.0161 & $\begin{array}{r}0.1134 \\
(0.0138)\end{array}$ & 0.0136 & $\begin{array}{r}0.0844 \\
(0.0138)\end{array}$ & 0.0096 \\
\hline 1993 Year Effect & $\begin{array}{r}0.1611 \\
(0.0130)\end{array}$ & 0.0238 & $\begin{array}{r}0.1603 \\
(0.0137)\end{array}$ & 0.0197 & $\begin{array}{r}0.1269 \\
(0.0136)\end{array}$ & 0.0148 \\
\hline 1994 Year Effect & $\begin{array}{r}0.2276 \\
(0.0126)\end{array}$ & 0.0346 & $\begin{array}{r}0.2436 \\
(0.0132)\end{array}$ & 0.0313 & $\begin{array}{r}0.1146 \\
(0.0134)\end{array}$ & 0.0133 \\
\hline 1995 Year Effect & $\begin{array}{r}0.2194 \\
(0.0126)\end{array}$ & 0.0332 & $\begin{array}{r}0.2344 \\
(0.0132)\end{array}$ & 0.0299 & $\begin{array}{r}0.0751 \\
(0.0134)\end{array}$ & 0.0085 \\
\hline 1996 Year Effect & $\begin{array}{r}0.2240 \\
(0.0126)\end{array}$ & 0.0340 & $\begin{array}{r}0.2508 \\
(0.0132)\end{array}$ & 0.0323 & $\begin{array}{r}0.0884 \\
(0.0135)\end{array}$ & 0.0101 \\
\hline Age & & & $\begin{array}{r}0.0060 \\
(0.0019)\end{array}$ & 0.0007 & $\begin{array}{r}0.0060 \\
(0.0019)\end{array}$ & 0.0006 \\
\hline Age Squared/100 & & & $\begin{array}{r}-0.0217 \\
(0.0024)\end{array}$ & -0.0024 & $\begin{array}{r}-0.0177 \\
(0.0024)\end{array}$ & -0.0019 \\
\hline High School & & & $\begin{array}{r}-0.2303 \\
(0.0065)\end{array}$ & -0.0265 & $\begin{array}{r}-0.2115 \\
(0.0067)\end{array}$ & -0.0235 \\
\hline College & & & $\begin{array}{r}-0.5076 \\
(0.0128)\end{array}$ & -0.0416 & $\begin{array}{r}-0.5996 \\
(0.0136)\end{array}$ & -0.0448 \\
\hline Married & & & $\begin{array}{r}-0.8078 \\
(0.0219)\end{array}$ & -0.0919 & $\begin{array}{r}-0.8699 \\
(0.0225)\end{array}$ & -0.0962 \\
\hline Number of Children & & & $\begin{array}{r}-0.0065 \\
(0.0179)\end{array}$ & -0.0007 & $\begin{array}{r}0.0305 \\
(0.0183)\end{array}$ & 0.0033 \\
\hline MarriedNumber of Children & & & $\begin{array}{r}-0.0661 \\
(0.0065)\end{array}$ & -0.0074 & $\begin{array}{r}-0.0551 \\
(0.0066)\end{array}$ & -0.0060 \\
\hline Major City & & & $\begin{array}{r}-0.0419 \\
(0.0065)\end{array}$ & -0.0047 & $\begin{array}{r}0.0157 \\
(0.0066)\end{array}$ & 0.0017 \\
\hline Social Assistance Norm*(12/35200) & & & $\begin{array}{r}0.2558 \\
(0.0265)\end{array}$ & 0.0287 & $\begin{array}{r}0.2102 \\
(0.0271)\end{array}$ & 0.0228 \\
\hline
\end{tabular}

Continued... 
Table 5 Continued:

Immigrant: Non-Refugee Country

$\begin{array}{rlrl}0.4229 & 0.0631 & 0.4664 & 0.0588 \\ (0.0099) & & (0.0106) & \\ 0.0041 & 0.0006 & -0.0634 & -0.0069 \\ (0.0121) & & (0.0127) & \\ 0.7444 & 0.1441 & 0.7638 & 0.1284 \\ (0.0103) & & (0.0108) & \end{array}$

$0.8423 \quad 0.1141$

$(0.0253)$

Immigrant: Nordic Country

Immigrant: Refugee Country

$0.0103)$

$-0.0261 \quad-0.0028$

(0.0130)

$1.1091 \quad 0.2126$

Arrival 1986-90

$(0.0269)$

$\begin{array}{ll}-0.2746 & -0.0249\end{array}$

(0.0282)

$-0.3222 \quad-0.0276$

Arrival 1981-85

(0.0298)

$-0.3924 \quad-0.0323$

Arrival 1976-80

$(0.0280)$

$\begin{array}{ll}-0.5391 & -0.0419\end{array}$

Arrival 1968-75

$(0.0265)$

Arrival $1986-90 *$ Refugee Country

$-0.3173 \quad-0.0274$

(0.0313)

$-0.8015 \quad-0.0473$

Arrival $1981-85^{\star}$ Refugee Country

(0.0350)

$-1.0250-0.0516$

Arrival $1976-80^{\star}$ Refugee Country

(0.0345)

$\begin{array}{ll}-0.9924 & -0.0501\end{array}$

Arrival $1968-75^{\star}$ Refugee Country

(0.0381)

Number of Observations

407,999

407,999

407,999

Log Likelihood 
Table 6.

OLS Models of Months on Welfare.

See the notes to Table 5 .

\begin{tabular}{|c|c|c|c|}
\hline Variable & $\begin{array}{c}\text { Model } 1 \\
\text { Estimated } \\
\text { Coefficient }\end{array}$ & $\begin{array}{c}\text { Model } 2 \\
\text { Estimated } \\
\text { Coefficient }\end{array}$ & $\begin{array}{c}\text { Model } 3 \\
\text { Estimated } \\
\text { Coefficient }\end{array}$ \\
\hline \multirow[t]{2}{*}{ Constant } & 3.4765 & 2.7909 & 3.0017 \\
\hline & $(0.0396)$ & $(0.1348)$ & $(0.1321)$ \\
\hline \multirow[t]{2}{*}{1991 Year Effect } & 0.2429 & 0.2628 & 0.2399 \\
\hline & $(0.0476)$ & $(0.0467)$ & $(0.0459)$ \\
\hline \multirow[t]{2}{*}{1992 Year Effect } & 0.2563 & 0.2901 & 0.2256 \\
\hline & $(0.0471)$ & $(0.0462)$ & $(0.0454)$ \\
\hline \multirow[t]{2}{*}{1993 Year Effect } & 0.4851 & 0.5453 & 0.4525 \\
\hline & $(0.0463)$ & $(0.0455)$ & $(0.0447)$ \\
\hline \multirow[t]{2}{*}{1994 Year Effect } & 0.8424 & 0.9527 & 0.4637 \\
\hline & $(0.0445)$ & $(0.0437)$ & $(0.0433)$ \\
\hline \multirow[t]{2}{*}{1995 Year Effect } & 1.1273 & 1.2203 & 0.6210 \\
\hline & $(0.0444)$ & $(0.0436)$ & $(0.0434)$ \\
\hline \multirow{2}{*}{1996 Year Effect } & 1.5158 & 1.5948 & 0.9741 \\
\hline & $(0.0443)$ & $(0.0435)$ & $(0.0433)$ \\
\hline \multirow[t]{2}{*}{ Age } & & 0.0120 & 0.0099 \\
\hline & & $(0.0057)$ & $(0.0056)$ \\
\hline \multirow[t]{2}{*}{ Age Squared/100 } & & 0.0405 & 0.0492 \\
\hline & & $(0.0075)$ & $(0.0073)$ \\
\hline \multirow[t]{2}{*}{ High School } & & -0.8157 & -0.8151 \\
\hline & & $(0.0195)$ & $(0.0192)$ \\
\hline \multirow[t]{2}{*}{ College } & & -0.5834 & -1.0109 \\
\hline & & $(0.0415)$ & $(0.0411)$ \\
\hline \multirow[t]{2}{*}{ Married } & & -0.0701 & -0.3831 \\
\hline & & $(0.0637)$ & $(0.0625)$ \\
\hline \multirow[t]{2}{*}{ Number of Children } & & 0.1074 & 0.1483 \\
\hline & & $(0.0507)$ & $(0.0496)$ \\
\hline \multirow[t]{2}{*}{ Married*Number of Children } & & 0.1433 & 0.1583 \\
\hline & & $(0.0175)$ & $(0.0172)$ \\
\hline \multirow[t]{2}{*}{ Major City } & & 0.1499 & 0.3595 \\
\hline & & $(0.0194)$ & $(0.0192)$ \\
\hline \multirow[t]{2}{*}{ Social Assistance Norm*(12/35200) } & & 0.0563 & 0.0485 \\
\hline & & $(0.0752)$ & $(0.0737)$ \\
\hline \multirow[t]{2}{*}{ Immigrant: Non-Refugee Country } & 1.0212 & 0.8255 & 2.1070 \\
\hline & $(0.0343)$ & $(0.0343)$ & $(0.0672)$ \\
\hline \multirow[t]{2}{*}{ Immigrant: Nordic Country } & -0.5274 & -0.5609 & -0.4110 \\
\hline & $(0.0406)$ & $(0.0402)$ & $(0.0409)$ \\
\hline \multirow[t]{2}{*}{ Immigrant: Refugee Country } & 1.6709 & 1.5680 & 1.6970 \\
\hline & $(0.0325)$ & $(0.0322)$ & $(0.0674)$ \\
\hline
\end{tabular}

Continued... 
Table 6 Continued:

Arrival 1986-90

$-1.1064$

$(0.0754)$

Arrival 1981-85

$-1.4951$

$(0.0835)$

Arrival 1976-80

$-1.5155$

$(0.0775)$

Arrival 1968-75

$-1.7727$

$(0.0730)$

Arrival $1986-90^{*}$ Refugee Country

$-0.4461$

$(0.0804)$

Arrival $1981-85^{\star}$ Refugee Country

$-1.2134$

$(0.0951)$

Arrival $1976-80^{\star}$ Refugee Country

$-1.6630$

$(0.0952)$

Arrival $1968-75^{\star}$ Refugee Country

$-1.6031$

$(0.1100)$

Number of Observations

150,209

150,209

150,209

$R$ Square 
Table 7.

Random Effects Probit Model of Welfare Participation.

See the notes to Table 5.

\begin{tabular}{|c|c|c|c|c|c|c|}
\hline \multirow{2}{*}{$\begin{array}{l}\text { Group: } \\
\text { Variable }\end{array}$} & \multicolumn{2}{|c|}{ Natives } & \multicolumn{2}{|c|}{$\begin{array}{c}\text { Immigrants } \\
\text { (Non-Refugee Country) }\end{array}$} & \multicolumn{2}{|c|}{$\begin{array}{l}\text { Immigrants } \\
\text { (Refugee Country) }\end{array}$} \\
\hline & $\begin{array}{l}\text { Estimated } \\
\text { Coefficient } \\
\end{array}$ & $\begin{array}{c}\text { Marginal } \\
\text { Effect } \\
\end{array}$ & $\begin{array}{l}\text { Estimated } \\
\text { Coefficient } \\
\end{array}$ & $\begin{array}{c}\text { Marginal } \\
\text { Effect } \\
\end{array}$ & $\begin{array}{l}\text { Estimated } \\
\text { Coefficient } \\
\end{array}$ & $\begin{array}{c}\text { Marginal } \\
\text { Effect } \\
\end{array}$ \\
\hline Constant & $\begin{array}{r}-3.0434 \\
(0.1748)\end{array}$ & & $\begin{array}{r}1.4867 \\
(0.3017)\end{array}$ & 0.0969 & $\begin{array}{r}0.8934 \\
(0.3279)\end{array}$ & 0.0582 \\
\hline 1991 Year Effect & $\begin{array}{r}0.0815 \\
(0.0295)\end{array}$ & 0.0053 & $\begin{array}{r}-0.0304 \\
(0.0516)\end{array}$ & -0.0020 & $\begin{array}{r}0.2722 \\
(0.0649)\end{array}$ & 0.0177 \\
\hline 1992 Year Effect & $\begin{array}{r}0.1702 \\
(0.0291)\end{array}$ & 0.0111 & $\begin{array}{l}-0.0458 \\
(0.0549)\end{array}$ & -0.0030 & $\begin{array}{r}0.2409 \\
(0.0710)\end{array}$ & 0.0157 \\
\hline 1993 Year Effect & $\begin{array}{r}0.3085 \\
(0.0286)\end{array}$ & 0.0201 & $\begin{array}{r}-0.0513 \\
(0.0602)\end{array}$ & -0.0033 & $\begin{array}{r}0.2545 \\
(0.0804)\end{array}$ & 0.0166 \\
\hline 1994 Year Effect & $\begin{array}{r}0.2630 \\
(0.0290)\end{array}$ & 0.0171 & $\begin{array}{r}0.0022 \\
(0.0675)\end{array}$ & 0.0001 & $\begin{array}{r}0.3371 \\
(0.0916)\end{array}$ & 0.0220 \\
\hline 1995 Year Effect & $\begin{array}{r}0.2150 \\
(0.0295)\end{array}$ & 0.0140 & $\begin{array}{r}-0.0001 \\
(0.0762)\end{array}$ & 0.0000 & $\begin{array}{r}0.4701 \\
(0.1047)\end{array}$ & 0.0306 \\
\hline 1996 Year Effect & $\begin{array}{r}0.3019 \\
(0.0297)\end{array}$ & 0.0197 & $\begin{array}{r}0.0034 \\
(0.0853)\end{array}$ & 0.0002 & $\begin{array}{r}0.5142 \\
(0.1189)\end{array}$ & 0.0335 \\
\hline Age & $\begin{array}{r}0.0141 \\
(0.0074)\end{array}$ & 0.0009 & $\begin{array}{r}0.0004 \\
(0.0134)\end{array}$ & 0.00001 & $\begin{array}{r}0.0056 \\
(0.0150)\end{array}$ & 0.0004 \\
\hline Age Squared/100 & $\begin{array}{r}-0.0612 \\
(0.0096)\end{array}$ & -0.0040 & $\begin{array}{r}0.0112 \\
(0.0173)\end{array}$ & 0.0007 & $\begin{array}{r}0.0346 \\
(0.0194)\end{array}$ & 0.0023 \\
\hline High School & $\begin{array}{r}-0.2787 \\
(0.0268)\end{array}$ & -0.0182 & $\begin{array}{r}0.0392 \\
(0.0465)\end{array}$ & 0.0026 & $\begin{array}{r}0.3069 \\
(0.0510)\end{array}$ & 0.0200 \\
\hline College & $\begin{array}{r}-1.2782 \\
(0.0747)\end{array}$ & -0.0833 & $\begin{array}{r}0.1636 \\
(0.1070)\end{array}$ & 0.0107 & $\begin{array}{r}0.5396 \\
(0.0954)\end{array}$ & 0.0352 \\
\hline Married & $\begin{array}{r}-1.3889 \\
(0.0932)\end{array}$ & -0.0905 & $\begin{array}{r}0.3397 \\
(0.1371)\end{array}$ & 0.0221 & $\begin{array}{r}0.0635 \\
(0.1305)\end{array}$ & 0.0041 \\
\hline Number of Children & $\begin{array}{r}-0.0037 \\
(0.0737)\end{array}$ & -0.0002 & $\begin{array}{r}0.1168 \\
(0.1091)\end{array}$ & 0.0076 & $\begin{array}{r}-0.0782 \\
(0.1072)\end{array}$ & -0.0051 \\
\hline Married*Number of Children & $\begin{array}{r}0.0050 \\
(0.0263)\end{array}$ & 0.0003 & $\begin{array}{r}-0.0815 \\
(0.0404)\end{array}$ & -0.0053 & $\begin{array}{r}-0.1279 \\
(0.0394)\end{array}$ & -0.0083 \\
\hline Major City & $\begin{array}{r}0.1368 \\
(0.0285)\end{array}$ & 0.0089 & $\begin{array}{r}-0.1455 \\
(0.0470)\end{array}$ & -0.0095 & $\begin{array}{r}-0.0832 \\
(0.0485)\end{array}$ & -0.0054 \\
\hline SA Norm*(12/35200) & $\begin{array}{r}0.2368 \\
(0.1107)\end{array}$ & 0.0154 & $\begin{array}{r}-0.0902 \\
(0.1625)\end{array}$ & -0.0059 & $\begin{array}{r}0.2412 \\
(0.1570)\end{array}$ & 0.0157 \\
\hline Nordic Immigrant & & & $\begin{array}{r}-0.0235 \\
(0.0133)\end{array}$ & -0.0023 & & \\
\hline Years Since Migration & & & $\begin{array}{r}-0.0408 \\
(0.0165)\end{array}$ & -0.0027 & $\begin{array}{c}-0.1972 \\
(0.0221)\end{array}$ & -0.0129 \\
\hline Years Since Mig. Squared/100 & & & $\begin{array}{r}-0.0160 \\
(0.0348)\end{array}$ & -0.0010 & $\begin{array}{r}0.3520 \\
(0.0565)\end{array}$ & 0.0229 \\
\hline
\end{tabular}

Continued... 
Table 7 Continued:

Arrival 1986-90

$-0.2505$

$-0.0163$

$0.1054 \quad 0.0069$

$(0.0998)$

$(0.1245)$

Arrival 1981-85

$\begin{array}{llll}-0.0954 & -0.0062 & -0.1223 & -0.0080\end{array}$

$(0.1552)$

(0.2079)

Arrival 1976-80

$-0.0048 \quad-0.0003$

$-0.0917-0.0060$

$(0.2032)$

$(0.2840)$

Arrival 1968-75

$\begin{array}{llll}0.0024 & 0.0002 & 0.2615 & 0.0170\end{array}$

(0.2659)

$(0.3814)$

$\operatorname{Var}(\mu)$

2.7848

Log Likelihood

$-71,775$

Sample Size

407,999 
Table 8.

Random Effects Model of Months on Welfare.

See the notes to Table 5.

\begin{tabular}{|c|c|c|c|c|c|}
\hline \multirow{2}{*}{$\begin{array}{l}\text { Group: } \\
\text { Variable }\end{array}$} & \multirow{2}{*}{$\begin{array}{c}\text { Natives } \\
\text { Estimated } \\
\text { Coefficient }\end{array}$} & \multicolumn{2}{|c|}{$\begin{array}{c}\text { Immigrants } \\
\text { (Non-Refugee Country) }\end{array}$} & \multicolumn{2}{|c|}{$\begin{array}{c}\text { Immigrants } \\
\text { (Refugee Country) }\end{array}$} \\
\hline & & $\begin{array}{l}\text { Estimated } \\
\text { Coefficient } \\
\end{array}$ & $\begin{array}{c}\text { Total Estimated } \\
\text { Effect } \\
\end{array}$ & $\begin{array}{l}\text { Estimated } \\
\text { Coefficient } \\
\end{array}$ & $\begin{array}{c}\text { Total Estimated } \\
\text { Effect } \\
\end{array}$ \\
\hline Constant & $\begin{array}{r}1.1039 \\
(0.2915)\end{array}$ & $\begin{array}{r}3.5260 \\
(0.4487)\end{array}$ & & $\begin{array}{r}3.1211 \\
(0.4078)\end{array}$ & \\
\hline 1991 Year Effect & $\begin{array}{r}0.0796 \\
(0.0600)\end{array}$ & $\begin{array}{r}-0.0549 \\
(0.0973)\end{array}$ & 0.0247 & $\begin{array}{r}0.2693 \\
(0.1088)\end{array}$ & 0.2940 \\
\hline 1992 Year Effect & $\begin{array}{r}0.1604 \\
(0.0590)\end{array}$ & $\begin{array}{l}-0.0075 \\
(0.0991)\end{array}$ & 0.1529 & $\begin{array}{r}0.0187 \\
(0.1126)\end{array}$ & 0.1716 \\
\hline 1993 Year Effect & $\begin{array}{r}0.4627 \\
(0.0576)\end{array}$ & $\begin{array}{r}0.1619 \\
(0.1019)\end{array}$ & 0.6247 & $\begin{array}{r}-0.1351 \\
(0.1185)\end{array}$ & 0.4896 \\
\hline 1994 Year Effect & $\begin{array}{r}0.5966 \\
(0.0580)\end{array}$ & $\begin{array}{r}-0.0271 \\
(0.1075)\end{array}$ & 0.5695 & $\begin{array}{r}0.0207 \\
(0.1260)\end{array}$ & 0.5902 \\
\hline 1995 Year Effect & $\begin{array}{r}0.5236 \\
(0.0587)\end{array}$ & $\begin{array}{r}0.0325 \\
(0.1154)\end{array}$ & 0.5562 & $\begin{array}{r}0.5256 \\
(0.1366)\end{array}$ & 1.0817 \\
\hline 1996 Year Effect & $\begin{array}{r}0.9781 \\
(0.0586)\end{array}$ & $\begin{array}{r}0.1089 \\
(0.1230)\end{array}$ & 1.0870 & $\begin{array}{r}0.5555 \\
(0.1479)\end{array}$ & 1.6425 \\
\hline Age & $\begin{array}{r}0.1316 \\
(0.0112)\end{array}$ & $\begin{array}{r}-0.1008 \\
(0.0182)\end{array}$ & 0.0308 & $\begin{array}{r}-0.0938 \\
(0.0173)\end{array}$ & -0.0630 \\
\hline Age Squared/100 & $\begin{array}{r}-0.1633 \\
(0.0151)\end{array}$ & $\begin{array}{r}0.1508 \\
(0.0242)\end{array}$ & -0.0125 & $\begin{array}{r}0.1844 \\
(0.0226)\end{array}$ & 0.1719 \\
\hline High School & $\begin{array}{r}-0.6873 \\
(0.0403)\end{array}$ & $\begin{array}{r}0.0252 \\
(0.0625)\end{array}$ & -0.6621 & $\begin{array}{r}-0.0811 \\
(0.0585)\end{array}$ & -0.7432 \\
\hline College & $\begin{array}{r}-1.1839 \\
(0.1407)\end{array}$ & $\begin{array}{r}0.4849 \\
(0.1825)\end{array}$ & -0.6989 & $\begin{array}{r}-0.2126 \\
(0.1295)\end{array}$ & -0.9116 \\
\hline Married & $\begin{array}{r}-1.0326 \\
(0.1689)\end{array}$ & $\begin{array}{r}0.1810 \\
(0.2313)\end{array}$ & -0.8515 & $\begin{array}{r}0.8716 \\
(0.1811)\end{array}$ & 0.0201 \\
\hline Number of Children & $\begin{array}{r}-0.1755 \\
(0.1297)\end{array}$ & $\begin{array}{r}0.1162 \\
(0.1807)\end{array}$ & -0.0592 & $\begin{array}{r}0.5271 \\
(0.1452)\end{array}$ & 0.4679 \\
\hline Married*Number of Children & $\begin{array}{r}0.1269 \\
(0.0455)\end{array}$ & $\begin{array}{r}0.0075 \\
(0.0617)\end{array}$ & 0.1344 & $\begin{array}{r}-0.1275 \\
(0.0494)\end{array}$ & 0.0069 \\
\hline Major City & $\begin{array}{r}0.2847 \\
(0.0410)\end{array}$ & $\begin{array}{r}0.1594 \\
(0.0630)\end{array}$ & 0.4442 & $\begin{array}{r}-0.0942 \\
(0.0573)\end{array}$ & 0.3500 \\
\hline SA Norm(12/35200) & $\begin{array}{r}0.2003 \\
(0.1947)\end{array}$ & $\begin{array}{r}0.0622 \\
(0.2716)\end{array}$ & 0.2625 & $\begin{array}{r}-0.3938 \\
(0.2170)\end{array}$ & -0.1313 \\
\hline Nordic Immigrant & & $\begin{array}{r}-0.4334 \\
(0.0509)\end{array}$ & 3.0927 & & \\
\hline Years Since Migration & & $\begin{array}{r}-0.0241 \\
(0.0227)\end{array}$ & -0.0241 & $\begin{array}{r}-0.3220 \\
(0.0274)\end{array}$ & -0.3460 \\
\hline Years Since Mig. Squared/100 & & $\begin{array}{r}0.0107 \\
(0.0569)\end{array}$ & 0.0107 & $\begin{array}{r}0.7583 \\
(0.0883)\end{array}$ & 0.7690 \\
\hline
\end{tabular}

Continued... 
Table 8 Continued:

Arrival 1986-90

$-1.0623$

(0.1152)

Arrival 1981-85

$-1.4075$

$(0.1898)$

Arrival 1976-80

$-1.3199$

(0.2475)

Arrival 1968-75

$-1.4545$

(0.3133)

$\begin{array}{lrl}-1.0623 & 0.3278 & -0.7345 \\ & (0.1340) & \\ -1.4075 & 0.5894 & -0.8181 \\ & (0.2298) & \\ -1.3199 & 0.8330 & -0.4869 \\ & (0.3158) & \\ -1.4545 & 1.1361 & -0.3183 \\ & (0.4302) & \end{array}$

R-Squared

0.3333

Sample Size 
Table 9.

Estimated Effects of a Simulation in the Benefit Levels on Welfare Participation.

Note: Data are from Longitudinal Individual Data for Sweden (LINDA), 1990 to 1996. Simulation is based on estimated coefficients from Table 7.

\begin{tabular}{|c|c|c|c|c|}
\hline & Before Reform & After Reform & Difference & $\begin{array}{c}\text { Percentage } \\
\text { Change } \\
\end{array}$ \\
\hline Overall & $8.83 \%$ & $8.35 \%$ & -0.48 & $-5.4 \%$ \\
\hline $\begin{array}{l}\text { Natives } \\
\text { Immigrants }\end{array}$ & $3.85 \%$ & $3.62 \%$ & -0.23 & $-6.0 \%$ \\
\hline Non-Refugee Country & $9.20 \%$ & $8.90 \%$ & -0.30 & $-3.3 \%$ \\
\hline Refugee Country & $29.19 \%$ & $27.36 \%$ & -1.83 & $-6.3 \%$ \\
\hline
\end{tabular}


Figure 1. Immigration into Sweden, Annual Inflow and Proportion of Population, 1940-1998.

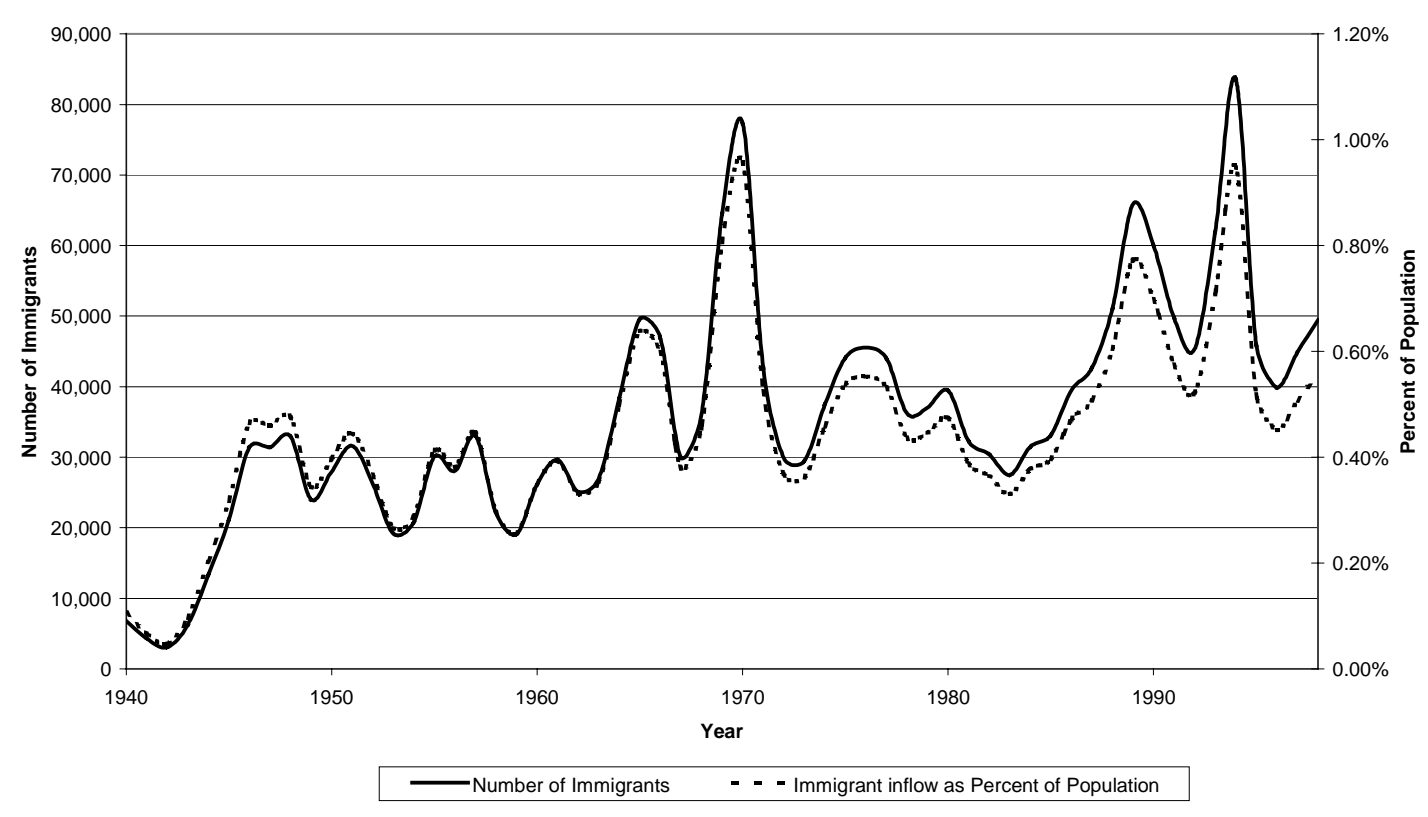

Figure 2. Real Expenditures on Social Assistence in Sweden, 1983-1998, in 1996 SEK

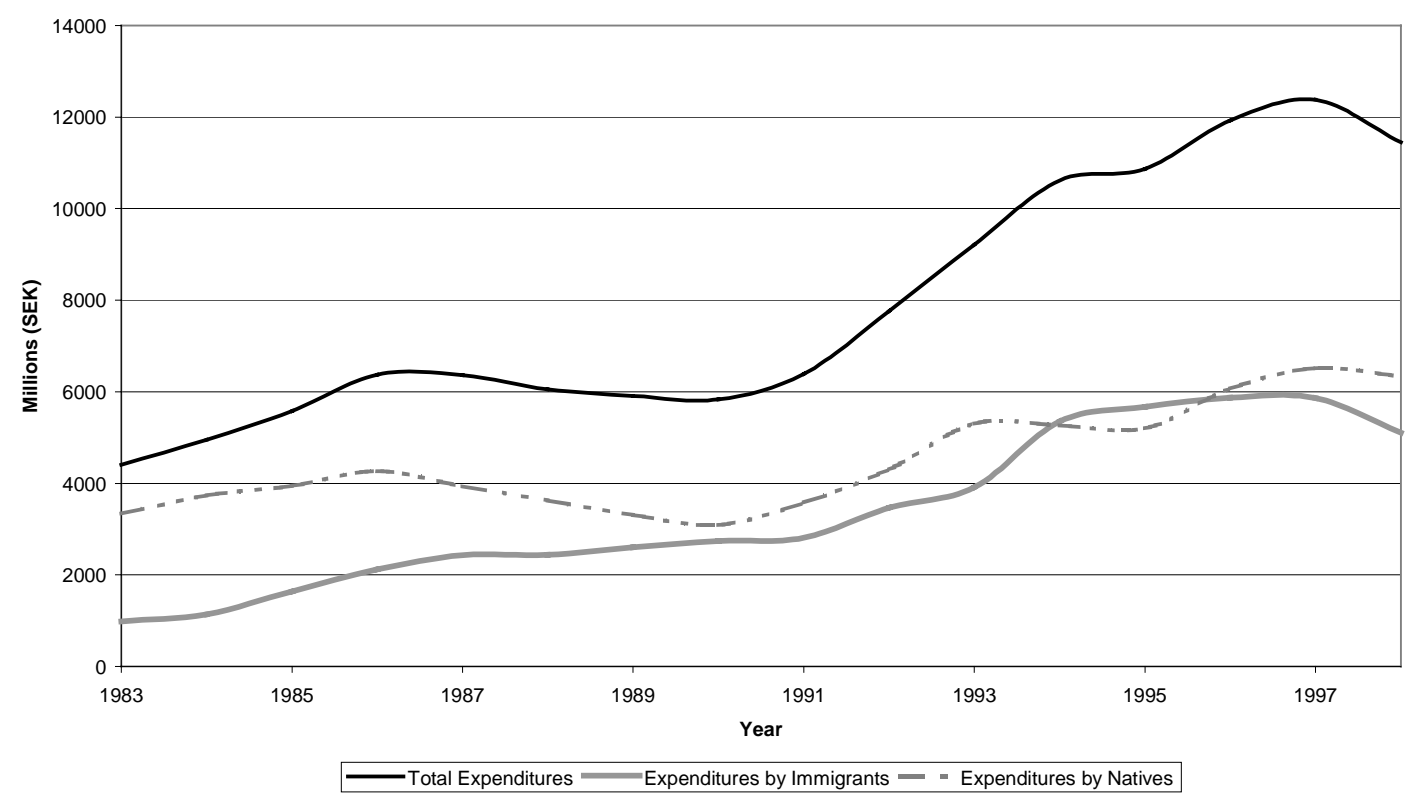


Figure 3. Observed Differences in Welfare Participation, Native Born Swedes and Immigrants, by Years Since Immigration

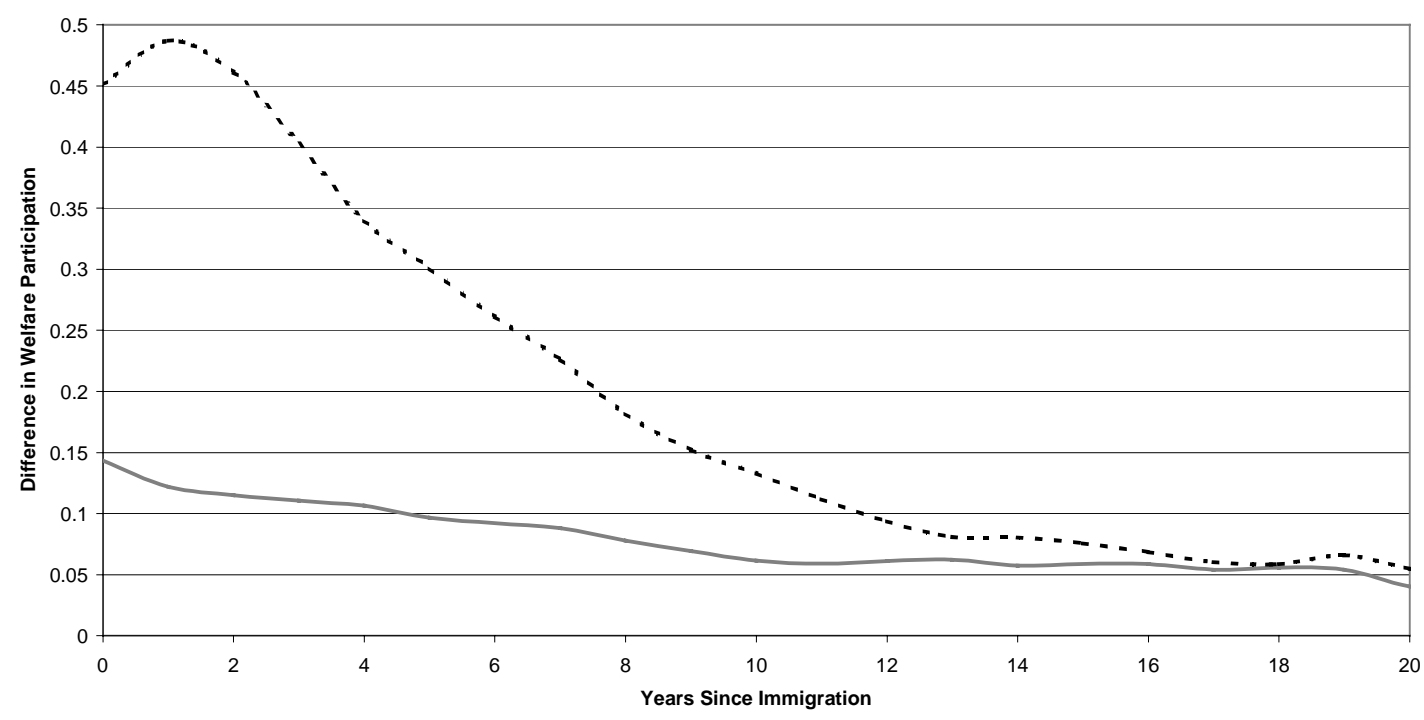

Non-Refugee Country - - - Refugee Country

Figure 4. Observed Differences in Months on Welfare, Native Born Swedes and Immigrants, by Years Since Immigration

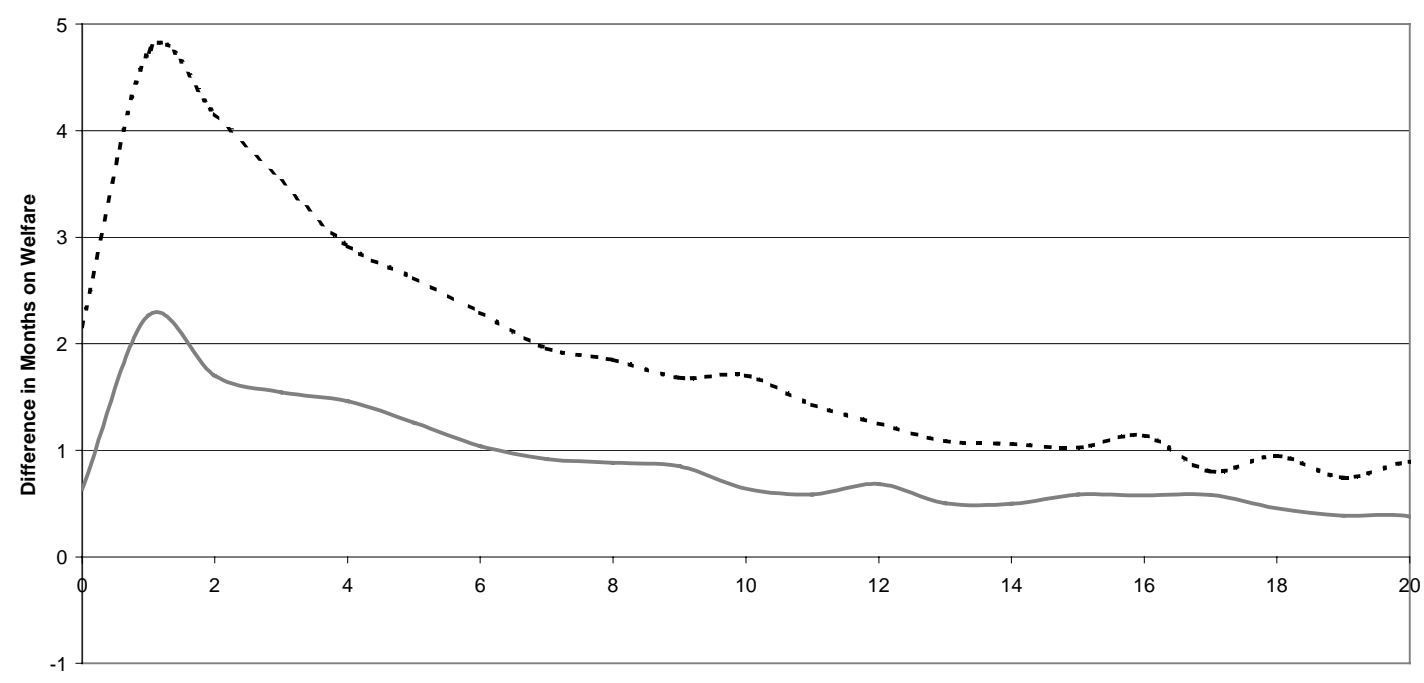

Years Since Immigration

-Non-Refugee Country - - - Refugee Country 
Figure 5. Predicted Difference in Welfare Participation between Native Born Swedes and Immigrants, by Years Since Migration, Age at Migration = 18, 1996 Baseline.

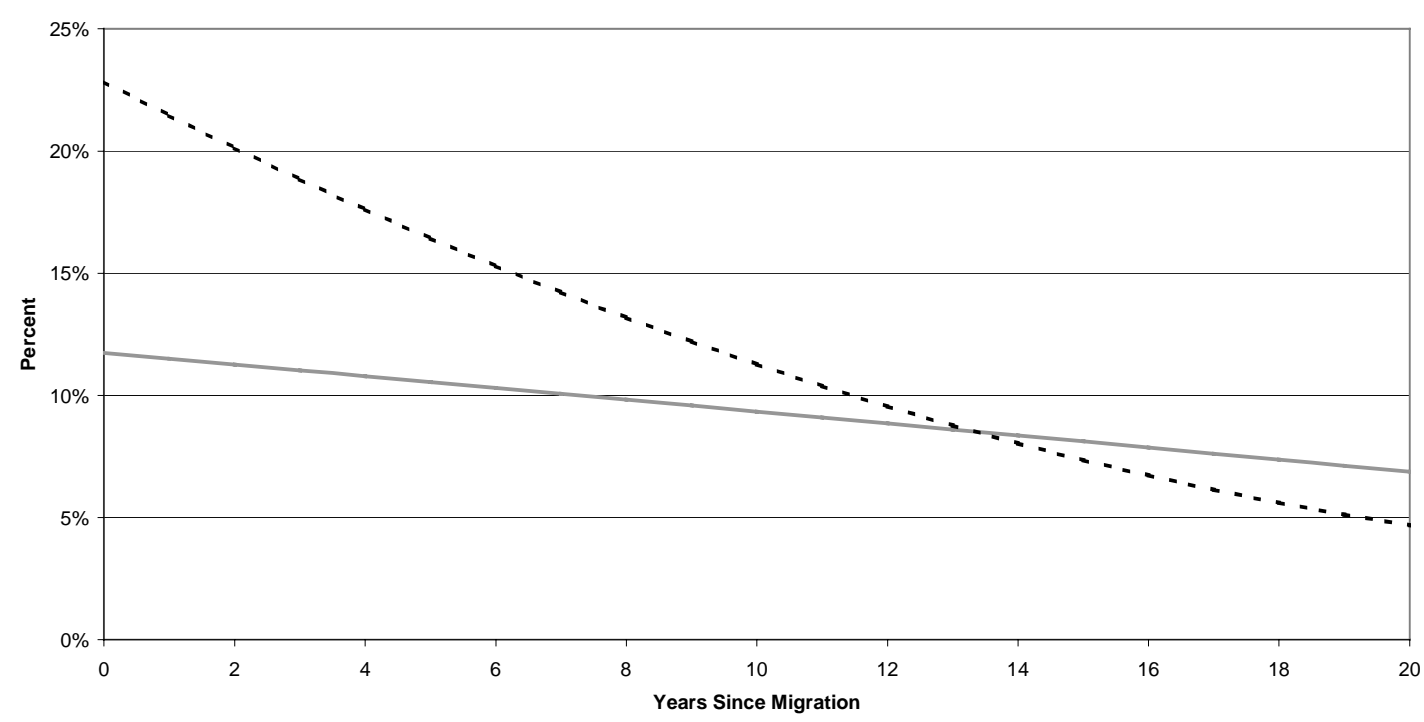

Non-Refugee Country - - - Refugee Country

Figure 6. Predicted Difference in Welfare Participation between Native Born Swedes and Immigrants from Non-Refugee Countries, by Arrival Cohort and Years Since Migration, Age at Migration = 18, 1996 Baseline.

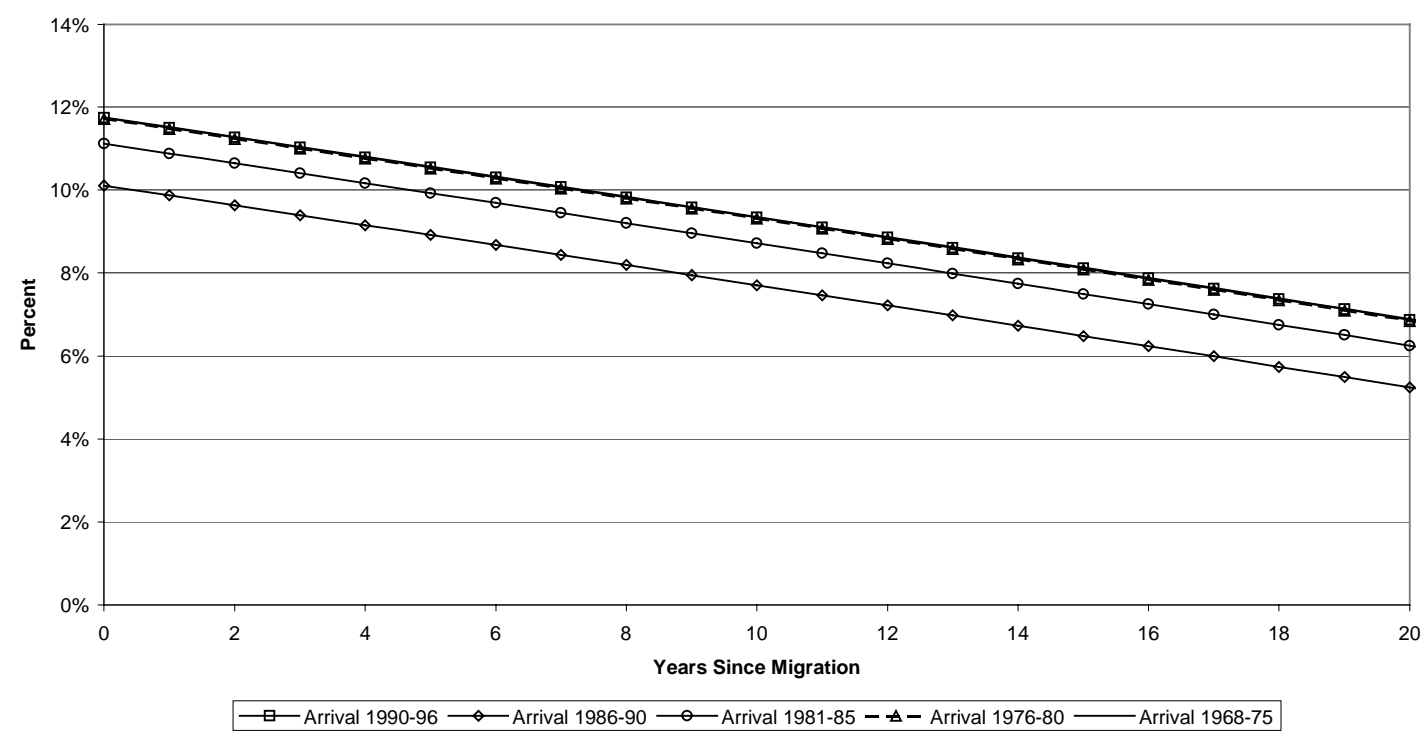


Figure 7. Predicted Difference in Welfare Participation between Native Born Swedes and Immigrants from Refugee Countries, by Arrival Cohort and Years Since Migration, Age at Migration = 18, 1996 Baseline.

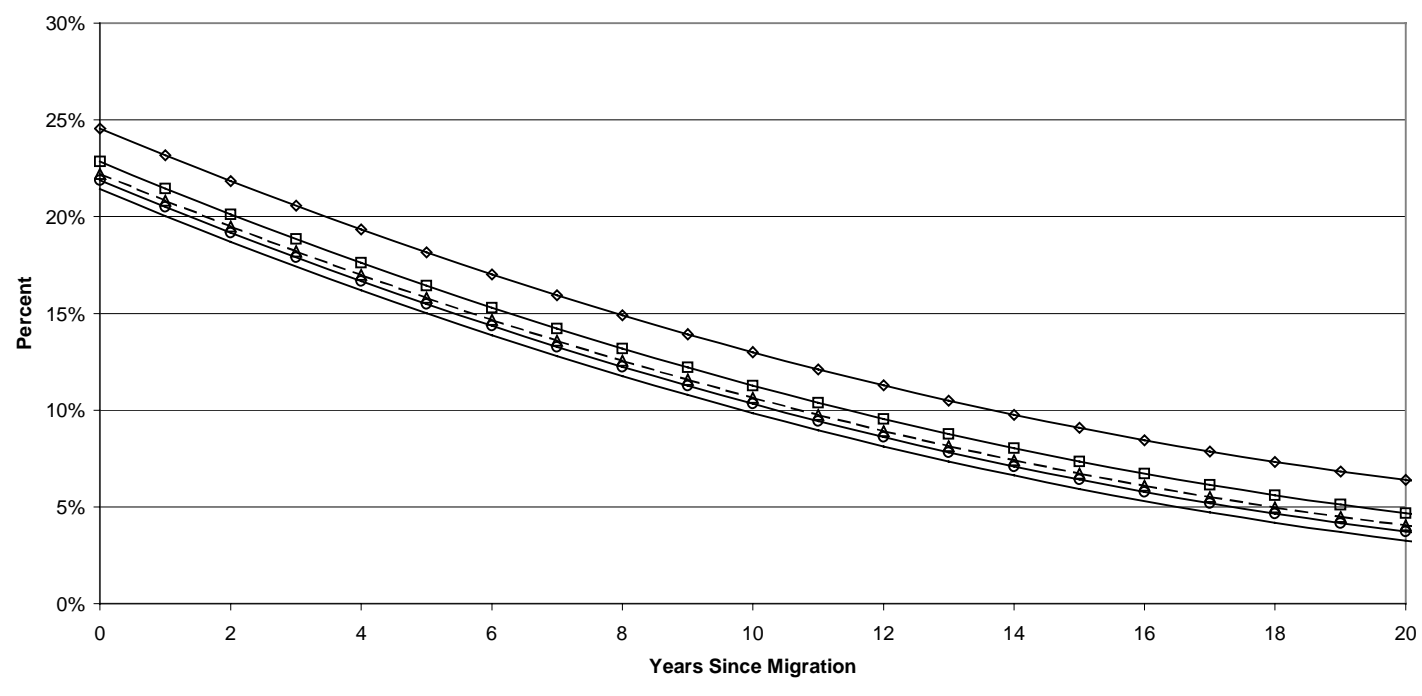

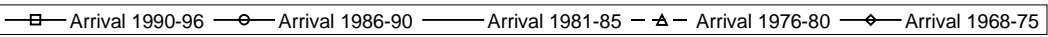

Figure 8. Predicted Difference in Months on Welfare between Native Born Swedes and Immigrants, by Years Since Migration, Age at Migration = 18, 1996 Baseline.

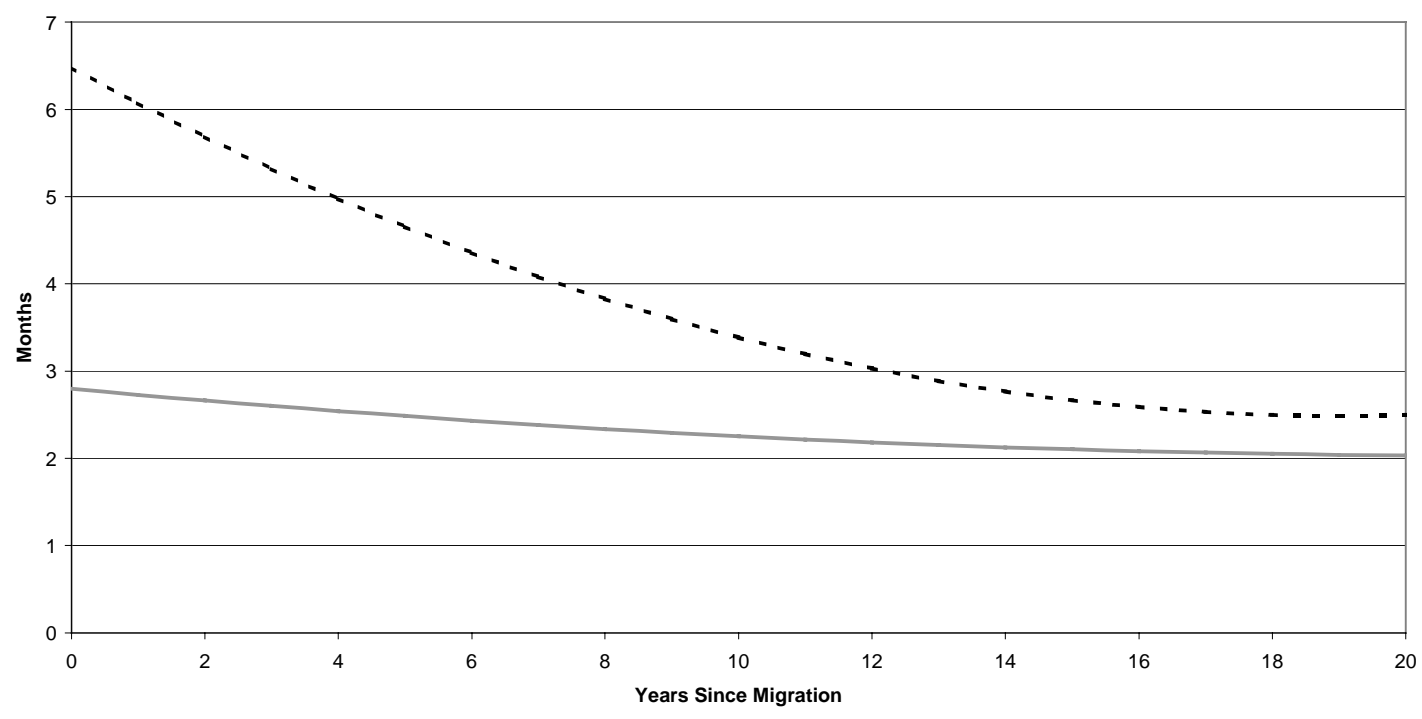

- Non-Refugee Country - - - Refugee Country 
Figure 9. Predicted Difference in Months on Welfare between Native Born Swedes and Immigrants from Non-Refugee Countries, by Arrival Cohort and Years Since Migration, Age at Migration = 18, 1996 Baseline.

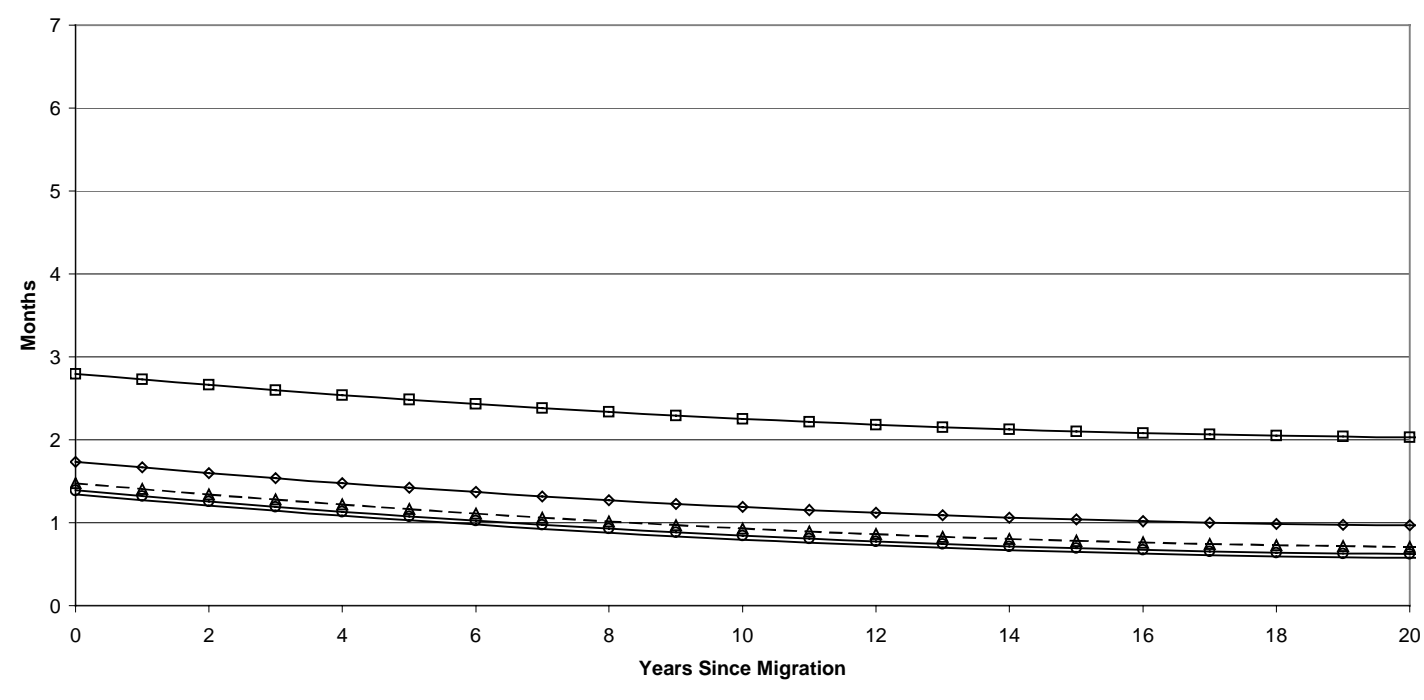

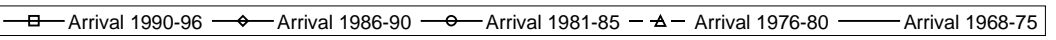

Figure 10. Predicted Difference in Months on Welfare between Native Born Swedes and Immigrants from Refugee Countries, by Arrival Cohort and Years Since Migration, Age at Migration = 18, 1996 Baseline.

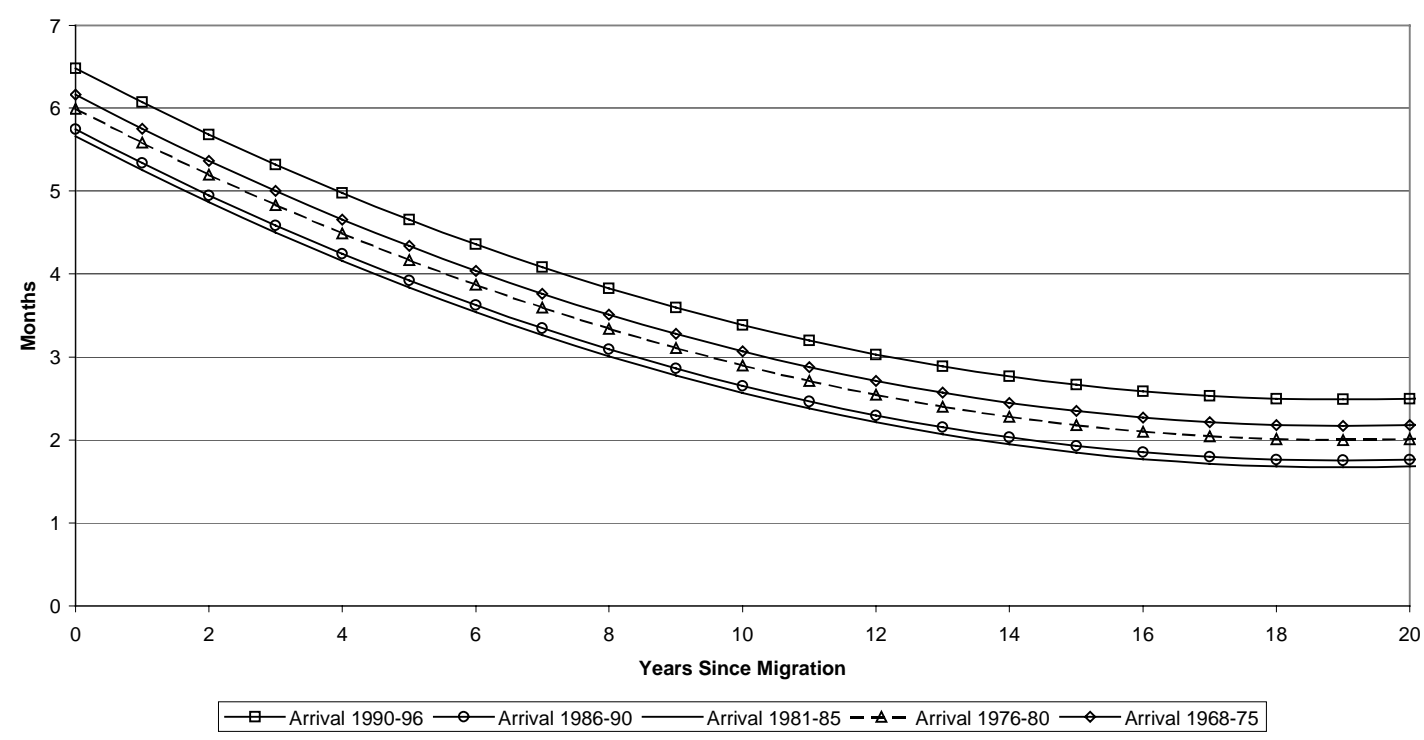

